Seminar Paper No. 574

INVESTMENT, PROPERTY RIGHTS AND

POLITICAL INSTABILITY

THEORY AND EVIDENCE

by

Jakob Svensson

INSTITUTE FOR INTERNATIONAL ECONOMIC STUDIES

University of Stockholm 
Seminar Paper No. 574

\section{INVESTMENT, PROPERTY RIGHTS AND}

POLITICAL INSTABIITY

THEORY AND EVIDENCE

by

Jakob Svensson

Seminar Papers are preliminary material circulated to stimulate discussion and critical comment.

July 1994

Institute for International Economic Studies

S-106 91 Stockholm

Sweden 


\title{
Investment, Property Rights and Political Instability Theory and Evidence
}

\author{
Jakob Svensson* \\ Institute for International Economic Studies \\ Stockholm University \\ S-106 91 Stockholm
}

Draft 1994-06-26

\begin{abstract}
Why do investment rates differ so markedly across countries in the developing world? This paper tries to explain these differences by studying a political model of institutional reform. The model implies that countries with more unstable and polarized political systems will have more inefficient legal systems, resulting in poorly enforced property rights and, thus, lower levels of domestic investment and higher levels of nonmarketable production and capital flight. These predictions of the model hold up when confronted with cross-country data for 101 countries. Extensive sensitivity analysis shows that the empirical results are robust to an ample of prospective statistical problems.
\end{abstract}

${ }^{*}$ I am grateful for many useful comments and suggestions by Torsten Persson. I thank Gunnar Jonsson, Nils Gottfries, Peter Svedberg and participants in seminars held at Stockholm University and Institute for International Economic Studies for comments. Alberto Alesina and Steve Knack kindly made their data available. 


\section{Introduction}

Why do investment and growth rates differ so markedly across countries in the developing world? Is there a common explanation for why some countries have experienced dramatic increases in real per capita GDP, with yearly investment rates above 30 percent, while others have stagnated, with investment rates below 5 percent? Table 1.1 displays average annual investment and growth data, as well as minimum, maximum and standard deviations figures for 82 developing countries between 1960-1985. ${ }^{1}$

Table $\mathbb{1 . 1}$

\begin{tabular}{lcccc}
\hline \hline & Africa & Asia & L. America & All \\
\hline Investment & 14.1 & 16.9 & 17.6 & 15.7 \\
Std Dev & 7.0 & 6.5 & 6.8 & 7.0 \\
Min & 4.2 & 5.9 & 7.1 & 4.2 \\
Max & 31.8 & 32.2 & 32.5 & 32.5 \\
\hline Growth & 1.0 & 3.3 & 1.5 & 1.6 \\
Std Dev & 2.0 & 2.2 & 1.4 & 2.1 \\
Min & -2.8 & 0.4 & -1.6 & -2.8 \\
Max & 5.4 & 7.4 & 4.4 & 7.4 \\
\hline Countries & 42 & 16 & 24 & 82 \\
\hline
\end{tabular}

On average African countries have lower investment and growth rates than countries in Latin America and Asia. However, there are large differences within each continent. The investment rate varies from 4.2 percent to almost 32 percent in Africa and the picture is similar in Latin America and Asia. Comparing growth figures, the divergences are just as striking. While some countries have seen their per capita income increase by more than fivefold since 1960, others have lower real GDP per capita 1985 than in 1960. Behind these figures, a glaring fact of development is hidden, namely that virtually every country that has experienced rapid and sustained growth of income has done so by industrializing. Similarly, in countries that have experienced economic stagnation and decline, there has been a shift in economic activity from modern or formal sector production towards informal sector activity and capital flight. ${ }^{2}$

One explanation for this "stylized fact", put forward by Douglas North (1981) and others, starts from the argument that the enforcement of property rights

\footnotetext{
${ }^{1}$ Constructed from Barro \& Wolf (1989) data set. Investment rate is defined as gross annual investment as share of income, average from 1960-1985, while growth is defined as average annual rate of growth of real per capita GDP from 1960-1985.

${ }^{2}$ See World Bank $(1988,1991)$.
} 
and contracts determines the incentive to invest in cumulative factors. Poorly enforced property rights due to, for instance, lax crime enforcement, weak court system, excessive regulations and poor patent protection, create a wedge between the marginal product of capital and the rate of return that can be privatley appropriated by investors. ${ }^{3}$ Thus, two countries with the same marginal product of capital will have different investment rates if the appropriable returns differ. Consequently, to explain differences in investment rates and growth one has to explain why property rights and contracts are enforced differently across countries. Table 1.2 displays one quantitative measure of property rights protection and contract enforcement across countries, ICRGS, defined in section 3.2. below. A high score on this measure indicate a more efficient property rights structure. On average Asian countries score better than countries in Africa and Latin America, but again the striking fact is the large differences within each continent.

Table $\mathbf{1 . 2}$

\begin{tabular}{lcccc}
\hline \hline & Africa & Asia & L. America & OECD \\
\hline ICRGS & 22.1 & 29.6 & 22.0 & 45.7 \\
Std Dev & 6.8 & 13.9 & 8.0 & 7.2 \\
Min & 11.0 & 10.8 & 8.4 & 15.8 \\
Max & 41.2 & 49.0 & 36.3 & 50.0 \\
\hline Countries & 30 & 15 & 22 & 22 \\
\hline
\end{tabular}

It is ultimately the state that specifies and enforces property rights and contracts by providing an efficient legal system. The question is then: why do we observe permissive legal systems in many developing countries? And why does not a rational, forward-looking government choose to reform the legal code, or alternatively invest in legal infrastructure?

In this paper, I try to explain this apparent form of collective irrationality as a result of political instability and polarization. Low investment in legal infrastructure is the rational choice of policymakers who maximize individual welfare of their constituency, or social or ethnic group, as opposed to social welfare. The idea is simple. Lack of investment in legal infrastructure results in poorly enforced property rights and weak contract enforcement. This breeds rent-seeking activities which reduce the privately appropriated marginal return to investment and increase the cost of doing business in the formal sector. As a result, the economic activity shifts towards nonmarketable production (e.g. subsistence farming) and foreign savings. ${ }^{4}$ The shift away from domestic investment in the formal sector constrains the future government's revenues collecting policies, due to higher

\footnotetext{
${ }^{3}$ De Soto (1989) reveals that for the majority of formal businesses in Peru, the single greatest expense in both money and time is costs imposed by the (mal)functioning of the legal institutions.

${ }^{4}$ The effects of weak legal systems and excessive rent-seeking are well-documented by, for instance, Bates (1987) and De Soto (1989).
} 
tax collection costs in the informal sector. Hence, by not reforming the legal system the current government discourages future governments from collecting taxes and spending them on goods and services that the current government does not value. ${ }^{5}$ Of course, this is more likely to happen in countries with more unstable and polarized political systems. Thus, if the current government faces a high risk of being thrown out of office the next period and if the spending program of the other government is very different, it could be rational for the government in office not to reform the country's legal institutions.

This paper is related to various strands of research. Tornell \& Velasco (1992) and Alesina \& Tabellini (1989), also explain capital flight and low domestic capital formation as a result of conflict among interest groups. In Tornell \& Velasco (1992), low investments emerge as a response to poor protection of property rights, whereas it is uncertainty of the fiscal policies of future governments that generates capital flight and low domestic capital formation in Alesina \& Tabellini (1989). Neither of the papers address the question why a rational government chooses not to invest in legal infrastructure. North (1981), on the other hand, stresses the relation between inefficient property rights and the revenue collecting incentives for the policymaker. According to North (1981), inefficient property rights exist because the cost of monitoring, metering and collecting taxes might lead to a situation in which a less efficient property rights structure yields more tax revenue for the ruler. In this paper, the instability of the political system is the underlying source of the inefficient legal system. Murphy, Shleifer \& Vishny $(1991,1993)$ also emphasize the negative effects of poorly enforced property rights and rent-seeking on growth. As in this paper, Murphy, Shleifer \& Vishny (1991) study the allocation of resources between formal sector production (cash-crop production) and nonmarketable production (subsistence farming). However, their focus is on the specific properties of the rent-seeking technology rather than how political incentives shape fiscal policies and institutional reforms.

The idea that the current government strategically uses a state variable to influence or constrain the policies of future governments has several other applications, starting with the papers by Persson \& Svensson (1989) and Tabellini \& Alesina (1990).$^{6}$ In particular, the model presented here is in some respect similar to the model in Cukierman, Edwards \& Tabellini (1992). However, Cukierman, Edwards \& Tabellini (1992) address the question of political instability and seigniorage, and not the question of how a country's political system governs the evolution of its legal institutions.

\footnotetext{
${ }^{5}$ There are other ways in which the level of rent-seeking in a country constrains future governments' fiscal policy. A previous version of this paper emphasized how interest groups in a society with poor laws and a permissive legal system can determine or influence government spending, through lobbying and corruption, leaving less resources for redistribution purposes for the incumbent policymaker.

${ }^{6}$ See Persson \& Tabellini (1994) for references.
} 
Finally, Alesina, Özler, Roubini \& Swagel (1992) present empirical evidence on the relationship between political instability and growth. They estimate a reduced form model where political instability directly affects growth, implying that the mechanism connecting instability with growth is not analyzed. In this paper I explicitly test a mechanism that connects political instability with investment.

This paper is organized as follows. In section 2 , the idea that political instability and polarization may induce the current government not to reform the legal system is formalized. This leads to two empirical predictions which are tested in section 3 , namely that countries with more unstable and polarized political systems will have less efficient legal institutions, resulting in lower levels of private investment. The main results of this paper are summarized in section 4 .

\section{A Political Model of Institutional Reforms}

In this section I will postulate a simple model which captures the general idea that institutional reforms may be influenced by strategic considerations. The central feature of the model is a distinction between fiscal policy and legal reform. Fiscal policy is the choice of tax rates and composition of government spending, while legal reform is a broad design of a property rights and contract structure in the economy. The important difference between the two is that a reform of the legal system is a process which takes time and resources, while fiscal policy can be implemented rather quickly. I show in this section that given political instability and polarization, the current government may invest too little in legal infrastructure with adverse effects on domestic investment.

To focus attention on the political effects, I assume throughout the paper that legal reform is costless. Adding resource costs for legal reform only serve to reinforce the results derived below. ${ }^{7}$

\subsection{The Model}

\subsubsection{The private sector}

Consider a small open economy lasting for two periods and producing one good in the modern sector. Let the price of this good be fixed, equal to unity. The utility function for a representative agent is given by;

$$
U=u\left(c_{1}\right)+\beta u\left(c_{2}\right)
$$

where $u\left(c_{t}\right)$ is a concave, twice continuously differentiable utility function, $\beta$ is a discount factor, and $c_{t}$ is consumption per capita. The subscript refers to time period $t, t=1,2$. In period 1 there is no production and agents derive their income from given initial endowments, $e$. In period 2 the good is produced in the

\footnotetext{
${ }^{7}$ See also footnote 27 .
} 
modern sector according to a concave technology, $y=a f(i)$, where $a$ is a measure of technology and $i$ is domestic investment per capita. The representative agent faces the choice in period 1 to either invest in the formal sector, $i$, with the return $R^{i}$ equal to the marginal product of capital, or to save in the traditional or informal sector (nonmarketable production), $d$, with a fixed return equal to $R$. Alternatively, $d$ could be interpreted as savings abroad (capital flight), with $R$ equal to the given world rate of interest.

The budget constraints for the representative agent are given by;

$$
\begin{gathered}
c_{1}=e-i-d \\
c_{2}=(1-\tau)\left[(1-\lambda) R^{i} i+R d\right]
\end{gathered}
$$

where $e$ is first period income and $\tau$ is a tax on second period income. ${ }^{8}$ The variable $\lambda$ is a rough measure of the efficiency of the legal system, broadly defined, with $\lambda \in[0,1)$, and where $\lambda=0$ is the most efficient legal system. As in Murphy, Shleifer \& Vishny $(1991,1993)$, I model the effect of poorly enforced property rights and weak contract enforcement as a fraction, $\lambda$, of domestic investment is wasted in protection and other costs of doing business in the formal sector. ${ }^{9}$

There are two ways to interpret this set-up. First, the representative agent is an entrepreneur facing the choice of either investing in a modern plant, $i$, or in foreign bonds, $d$. Second, the representative agent is a farmer facing the choice of either investing time and resources producing a cash crop, $i$, or continuing with subsistence farming, $d$. The enforcement of property rights and contracts is crucial for both choices.

\subsubsection{The government}

The government can be of two types, A and B. The two types randomly alternate in office. Irrespective of which government being in office in period 1, type A is in office in period 2 with probability $\pi$, and type $B$ with probability $(1-\pi)$. The measure of instability, $\pi$, is exogenous in this paper. Consequently, the link

\footnotetext{
${ }^{8}$ The assumption that the same tax rate applies to both $i$ and $d$ is made only for simplicity. All the results of the analysis would continue to hold if the two tax rates differed. The important assumption is that the return to $i$ relative $d$ does not change when taxes change, even though, total income in period 2 will change. This set-up is justified by the presumption that taxes in less developed countries are often of a general type, such as seigniorage, affecting income irrespective of how it is generated. The specification abstracts from one important complication. In countries with more sophisticated tax systems, capital flight will emerge also as an insurance against the risk of future taxation. However, this effect has already been extensively studied in the literature (see e.g. Alesina and Tabellini (1989) and the references given therein). Therefore, I neglect the "taxation-effect" in order to focus on the novel issue of how a country's political system governs the evolution of its formal institutions.

${ }^{9}$ In Murphy, Shleifer \& Vishny $(1991,1993)$ a fraction of profits in the productive sector is taken away by rent seekers. They study the allocation of talent (resources) between rent-seeking activities and the productive sector. The fraction is exogenous in their papers.
} 
between the likelihood of a government change and the economic conditions or the pursued economic policy in the country is not considered. ${ }^{10}$ The government can raise taxes and supply public goods. Government A:s goal is to maximize the welfare function $W^{A}$, defined as;

$$
W^{A}=E_{1}\left[u\left(c_{1}\right)+\beta\left(u\left(c_{2}\right)+G^{A}\left(g^{1}, g^{2}\right)\right)\right]
$$

where $E_{1}(\cdot)$ denotes the expectation operator. In equation (2.4), $g^{1}$ and $g^{2}$ are two public goods in per capita terms. For simplicity, with no loss of generality, these goods are only supplied in period 2. The $G^{A}\left(g^{1}, g^{2}\right)$ function is defined as in Cukierman, Edwards \& Tabellini (1992), namely;

$$
G^{A}=\left(\frac{1}{\alpha(1-\alpha)}\right) \min \left[\alpha g^{1},(1-\alpha) g^{2}\right]
$$

where $\alpha \in\left(0, \frac{1}{2}\right]$. Government B:s objective function, $W^{B}$, is defined as in (2.4) and (2.5), but with $\alpha$ replaced with $(1-\alpha)$. Thus, the two types differ in the relative weight assigned to the supplied public goods. The degree of polarization is parameterized by $\alpha$. The closer $\alpha$ is to 0 , the more the two governments disagree over fiscal policy. ${ }^{11}$ Consequently, as in Tabellini \& Alesina (1990) and Cukierman, Edwards \& Tabellini (1992), I assume that the two types disagree over the composition of public spending. This could be interpreted as a redistributive conflict since transfer systems in most developing countries are poor. ${ }^{12}$

Fiscal policy can be implemented rather quickly, whereas investment in legal infrastructure or a reform of the legal system is a time consuming process. I capture the greater inertia in reforming the legal system by assuming that $\lambda$ must be chosen one period in advance. Hence, the government in office in period 1 chooses investment in legal infrastructure, $\lambda$, while the government in power in period 2 chooses $\tau$ and the composition of the public goods, taking $\lambda$ as given.

I have assumed without loss of generality that both $i$ and $d$ are taxed at the same rate $\tau$. However, for the government the two tax bases differ. Because of higher tax-collection costs in the informal sector, a fraction $\mu, \mu \in(0,1]$, of total tax revenue from this sector is wasted in administrative and collection costs. Thus, for a given tax rate, $\tau$, and for a given level of total savings, $s=i+d$, the more capital held in the informal sector or held abroad, $d$, relative to domestic

\footnotetext{
${ }^{10}$ However, in the empirical analysis, I take the possibility of reverse causation into acount.

${ }^{11}$ In a previous version of this paper, I modeled polarization as arising from the fact that the economy consisted of two symmetric groups with their own political representatives, not only two types of governments. However, since I also assumed that the government could not differentiate with respect to taxes between the two groups, the analysis turned out to be almost identical to the one carried out in this paper.

${ }^{12}$ In practise, however, even in countries were the transfer system is poor, redistributive policy is implemented both by providing public goods and through indirect transfers. Examples of the later is interventions to change relative prices in favour for one group (Krueger (1993)) or by providing public employment to favoured groups (Gelb, Knight \& Sabot (1991)).
} 
investment, $i$, the less tax revenue is generated. This set-up is justified by the presumption that the good produced in the modern sector is easier to tax, that is has lower tax collection costs, since it must be moved through well-defined locations, such as harbors and ports. Furthermore it must have access to imported machines and inputs, and are often produced in larger quantities at fixed locations for a limited number of buyers. Nonmarketable production on the other hand needs no or limited imports and can be transported along almost any road or path and is produced in much smaller quantities.

Thus, the government budget constraint can be written as;

$$
\tau\left[(1-\lambda) R^{i} i+(1-\mu) R d\right]=z
$$

where $z$ is total government spending in per capita terms, equal to $z=g^{1}+g^{2}$. The parameter $\mu$ is exogenous throughout this paper, determined by the existing technology and the level of development in the country.

\subsection{Market equilibrium}

In period 1 the representative agent chooses total level of savings, $s$, and the allocation between investment in the modern sector, $i$, and nonmarketable production or foreign saving, $d$. I assume perfect competition in factor markets so that the equilibrium rate of return to domestic investment is equal to the marginal product of capital, $R^{i}$, which is given by;

$$
R^{i}=a f_{i}(i)>0, \text { and } f_{i i}(\cdot)<0 .
$$

The representative agent maximizes the utility function (2.1) subject to the two budget constraints (2.2) and (2.3), taking $R^{i}$ as given. The first-order conditions for this problem can be written as;

$$
\begin{gathered}
(1-\lambda) R^{i}=R \\
\frac{u_{c}\left(c_{1}\right)}{\beta u_{c}\left(c_{2}\right)}=\left(1-\tau^{e}\right) R
\end{gathered}
$$

where $\tau^{e}$ is the expected tax rate. The first-order conditions (2.8) and (2.9) are standard equilibrium conditions. Equation (2.8) states that in equilibrium the return to domestic investment and nonmarketable production or foreign savings is equal. The inefficient property rights structure, captured by the function $\lambda$, drives a wedge between the marginal product of capital and the opportunity cost of investment. Equation (2.9) is a condition for optimal intertemporal allocation. The tax on second period income drives a wedge between the marginal rate of substitution and the marginal rate of transformation, $R$. Assuming rational expectations $\tau^{e}=\tau$ in equilibrium. Throughout this paper, I assume that initial endowment, $e$, is large enough, so that the equilibrium condition (2.8) always holds with equality. 
The first-order conditions (2.8) and (2.9) together with (2.7), implicitly define $i$ and $d$ as functions of the parameters $R, a$, and the efficiency variable $\lambda$.

$$
\begin{aligned}
i^{*} & =I(\lambda ; R, a) \\
d^{*} & =D(\lambda ; R, a)
\end{aligned}
$$

Applying the implicit function theorem to equations (2.8) and (2.9), using the fact that $s=i+d$, yields the following proposition.

Proposition 1

(i) $\quad I_{\lambda}(\lambda ; R, a)=\frac{R^{i}}{(1-\lambda) a f_{i i}(\cdot)}<0$

(ii) $\quad I_{R}(\lambda ; R, a)=\frac{1}{(1-\lambda) a f_{i i}(\cdot)}<0$

(iii) $I_{a}(\lambda ; R, a)=-\frac{f_{i}(\cdot)}{a f_{i i}(\cdot)}>0$

(iv) $D_{\lambda}(\lambda ; R, a)=-I_{\lambda}(\lambda ; R, a)>0$

(v) $D_{r}(\lambda ; R, a)=-\frac{\beta(1-\tau)\left[u_{c c}\left(c_{2}\right) R(1-\tau)(i+d)+u_{c}\left(c_{2}\right)\right]}{u_{c c}\left(c_{1}\right)+\beta u_{c c}\left(c_{2}\right)[(1-\tau) R]^{2}}-I_{R}(\cdot) \geq 0$

(vi) $\quad D_{a}(\lambda ; R, a)=-I_{a}(\lambda ; R, a)<0$

Thus, a less efficient legal system discourages domestic investment and shifts savings towards nonmarketable production or capital flight. The reason for this is that a more inefficient legal system, resulting in poorly enforced property rights, lowers the privately appropriated marginal product of capital. For a given $\lambda$, the higher is the opportunity cost of investment, $R$, the lower is the level of domestic investment and the higher is the level of foreign saving. An increase in the productivity of domestic capital, captured by the parameter $a$, increases domestic investment as the relative return to investment will be higher. The effect of a change in $R$ on $d$ depends on the usual balancing of income and substitution effects. However, independent of income and substitution effects the relation between $R$ and $i$ is always negative as long as (2.8) holds.

\subsection{Economic policy with a given legal system.}

To solve the policy problem I start in period 2 and derive the equilibrium values of $\tau, g^{1}, g^{2}$, and $c_{2}$ as functions of the efficiency of the legal system, $\lambda$. In period $2, \lambda$ is given and the incumbent policymaker solves the static problem of maximizing $\left[u\left(c_{2}\right)+G\left(g^{1}, g^{2}\right)\right]$ subject to equation (2.6). I only describe the equilibrium when type $\mathrm{A}$ is in office. By symmetry, the solution for government $\mathrm{B}$ is the same for $\tau$, while solutions for $g^{1}$ and $g^{2}$ are found by replacing $(1-\alpha)$ with $\alpha$. 
The first step in solving the problem is to derive the optimal composition of public spending. For a given level of government spending, $z$, the optimal composition of public goods for government $\mathrm{A}$ is given by;

$$
g_{A}^{1 *}=(1-\alpha) z, \text { and } g_{A}^{2 *}=\alpha z
$$

Plugging (2.12) into the public consumption function (2.5) I get;

$$
G^{A}\left(g_{A}^{1 *}, g_{A}^{2 *}\right)=z
$$

Using the government budget constraint (2.6) and the fact that in equilibrium the return to domestic investment is equal to the opportunity cost of investment, the choice of the optimal size of public spending can simply be stated as;

$$
\underset{\{\tau\}}{\operatorname{Max}} u\left(c_{2}\right)+z
$$

After some transformations, the first-order condition for this problem is given by $;^{13}$

$$
u_{c}\left(c_{2}\right) \frac{(i+d)}{(i+(1-\mu) d)}=1
$$

Equation (2.14) compares the marginal utility of public and private consumption. Even though, ex post, a tax on total savings is not distortionary, as the private sector's savings decision is not affected, at an optimum the marginal utility of public consumption, unity, exceeds the marginal utility of private consumption, $u_{c}\left(c_{2}\right)$. This is a result of the wasted resources in collecting taxes captured by the parameter $\mu$. The lower domestic investment relative to nonmarketable production or capital flight the more resources are wasted in tax collection costs for every level of government spending.

The first-order condition (2.14), together with the budget constraints (2.3), (2.6) and the behavioral constraints (2.10) and (2.11), implicitly define $\tau, c_{2}$ and $z$ as functions of the efficiency of the legal institutions, $\lambda$, and the parameters $\mu$, $R$ and $a$.

$$
\begin{aligned}
\tau^{*} & =T(\lambda ; \mu, R, a) \\
c_{2}^{*} & =C(\lambda ; \mu ; R, a) \\
z^{*} & =Z(\lambda ; \mu, R, a)
\end{aligned}
$$

In period 2 , the government in office chooses the allocation of government spending and the tax rate $\tau$, taking $\lambda$ as given. To derive the equilibrium level of $\lambda$, I must determine how these choices depend on the property rights structure in

\footnotetext{
${ }^{13}$ The second-order condition is always satisfied, because of the concavity of $u(c)$.
} 
the economy. By applying the implicit function theorem to the first-order condition (2.14), using the constraints (2.3), (2.6), and Proposition 1, I arrive at the following lemma. ${ }^{14}$

Lemma

(i) $\quad T_{\lambda}(\lambda ; \mu, R, a)=\frac{-\mu I_{\lambda}(\cdot)}{u_{c c}\left(c_{2}\right) R\left[i^{*}+d^{*}\right]^{2}}<0$

(ii) $\quad C_{\lambda}(\lambda ; \mu, R, a)=-T_{\lambda}(\cdot) R\left[i^{*}+d^{*}\right]>0$

(iii) $\quad Z_{\lambda}(\lambda ; \mu, R, a)=T_{\lambda}(\cdot) R\left[i^{*}+(1-\mu) d^{*}\right]+\tau^{*} R \mu I_{\lambda}(\cdot)<0$

Thus, a less efficient legal system discourages the government in period 2 from collecting taxes. The reason for this is that for every level of public spending more resources are wasted in tax collection costs. Consequently, the level of private consumption increases. The efficiency of the legal system affects the level of public spending through two channels. First, a less efficient legal system implies reduced government spending since the equilibrium tax rate is lower. Second, as total savings have shifted towards nonmarketable production and capital flight, less revenue is generated for every $\tau$, which reinforces the negative effect on government revenue.

\subsection{The equilibrium level of investment in legal infrastructure}

The problem for the government in period 1 is to maximize expected utility with respect to $\lambda$. From Proposition 1, I know that $\lambda$ does not affect the equilibrium return to investment, $R$, and therefore neither total level of savings. This implies that the incumbent policymaker in period 1 faces the problem of maximizing the expected welfare as of period 2 , subject to the incentive constraints given in equations (2.16)-(2.17). Again I only characterize the equilibrium when type $A$ is in office in period 1. Because of symmetry the optimal legal system for government $\mathrm{B}$ is found by replacing $\pi$ with $(1-\pi)$.

As noted above, the utility of public consumption for government $\mathrm{A}$ when government $\mathrm{A}$ is in office determining the composition of public spending, is equal to the level of government spending, that is $G^{A}\left(g_{A}^{1 *}, g_{A}^{2 *}\right)=z$.

The optimal composition of public spending for government $\mathrm{B}$ is given by;

$$
g_{B}^{1 *}=\alpha z, \text { and } g_{B}^{2 *}=(1-\alpha) z
$$

Inserting the public goods functions $(2.18)$ in the $G^{A}(\cdot)$ function, gives the utility of public consumption for government $\mathrm{A}$, when government $\mathrm{B}$ is in power;

$$
G^{A}\left(g_{B}^{1 *}, g_{B}^{2 *}\right)=\left(\frac{1}{\alpha(1-\alpha)}\right) \min \left[\alpha^{2} z,(1-\alpha)^{2} z\right]=\left(\frac{\alpha}{(1-\alpha)}\right) z
$$

\footnotetext{
${ }^{14}$ Notice that because the G( $\left.\cdot\right)$ function is linear, there are no income effects of a less efficient legal system on government consumption. If the $G(\cdot)$ function instead was concave, some additional assumptions of income and substituion effects would have to be made for lemma 2 to hold.
} 
where $\left(\frac{\alpha}{(1-\alpha)}\right) \leq 1$. Using $(2.19)$ and the fact that government $A$ is in office in period 2 with probability $\pi$, and government $B$ is in office with probability $(1-\pi)$, the expected welfare as of period 2 for government $\mathrm{A}$ is:

$$
\pi\left[u\left(c_{2}\right)+z\right]+(1-\pi)\left[u\left(c_{2}\right)+\left(\frac{\alpha}{(1-\alpha)}\right) z\right]
$$

Plugging the incentive constraints (2.16)-(2.17) into (2.20) and rewriting, the maximization problem can be stated as;

$$
\underset{\{\lambda\}}{M a x} \quad u(C(\lambda ; \mu, R, a))+\omega(\pi, \alpha) Z(\lambda ; \mu, R, a)
$$

where $\omega(\pi, \alpha)=\pi+(1-\pi)\left(\frac{\alpha}{(1-\alpha)}\right)$. The first-order condition for this problem is ${ }^{15}$

$$
u_{c}(C(\cdot)) C_{\lambda}(\cdot)+\omega(\pi, \alpha) Z_{\lambda}(\cdot) \leq 0
$$

Equation (2.21) compares the marginal gain of a less efficient legal system, taking the form of higher private consumption, with the expected marginal cost of a less efficient legal system, taking the form of reduced public spending. Both effects are due to lower taxes, as increased nonmarketable production or capital flight relative to domestic investment makes it more costly to finance public consumption.

The first-order condition (2.21) implicitly defines the equilibrium legal system as a function of political instability, $\pi$, polarization, $\alpha$, and the parameters $\mu, R$ and $a$.

$$
\lambda^{*}=\Lambda(\pi, \alpha, \mu, R, a)
$$

Thus, I have the following proposition, which is formally proved in the appendix.

\section{Proposition 2.}

(i) $\Lambda(1, \alpha, \mu, R, a)=0 \quad$ and $\Lambda\left(\pi, \frac{1}{2}, \mu, R, a\right)=0$ for all $\pi, \alpha, \mu, R, a$.

(ii) If $\lambda^{*}>0$, then $\Lambda_{\pi}(\pi, \alpha, \cdot)<0$.

(iii) If $\lambda^{*}>0$, then $\Lambda_{\alpha}(\pi, \alpha, \cdot)<0$.

(iv) There exist $\hat{\pi}>0, \hat{\alpha}>0$, such that $\Lambda(\pi, \alpha, \cdot)>0$ for any $\pi<\hat{\pi}, \alpha<\hat{\alpha}$.

(v) $\Lambda_{\mu}(\cdot) \gtrless 0, \Lambda_{R}(\cdot) \geq 0, \Lambda_{a}(\cdot)>0$.

Thus, if the current government is certain to remain in office the next period, that is $\pi=1$, or if there is no polarization, that is $\alpha=\frac{1}{2}$, it is optimal for the government in office in period 1 to choose the most efficient legal system. However, the more polarized or instable system the less investment in legal infrastructure is carried out by the government in period 1 , even though it is costless to do so. The reason for this is purely strategic. Less efficient legal institutions promote

\footnotetext{
${ }^{15} \mathrm{I}$ assume the second-order condition is satisfied. As in all optimal taxation problems, this requires some assumptions of the third derivates of $u(c)$ and $f(\cdot)$.
} 
nonmarketable production or capital flight and discourage domestic investment, thereby affecting future governments tax bases. Ceteris paribus, the higher the share of total private saving held in the informal sector or abroad, the higher the collection costs of taxing the private sector. Hence, by not reforming the legal system the incumbent discourages the future government from collecting taxes and spending them on goods that are not valued by the current government. Or in other words, the lower $\alpha$ or the lower $\pi$ the lower the expected marginal cost of a less efficient legal system.

The effects of $R, \mu$, or $a$ on $\lambda^{*}$ depend on how these parameters affect the marginal gain and loss of a less efficient legal system, and are in this set up ambiguous.

Combining Propositions 1 and 2, I have the central result of the model: countries with more unstable and polarized political systems will have more inefficient legal systems, resulting in poorly enforced property rights and contracts and, thus, lower levels of domestic investment and higher levels of nonmarketable production or capital flight.

\section{The empirical evidence}

\subsection{From model to an empirical test}

In this section, I will test the positive implications of the model summarized in Proposition 1 and 2, on a sample of 101 countries for the period 1960 to 1985. The two key equations in the model are the investment function (2.10) and the equilibrium legal system equation (2.22). As shown in appendix A.2. it is possible to derive the following linear approximation of these functions;

$$
\begin{gathered}
i_{j}^{*}=\mathbf{x}_{j}^{\prime} \beta_{1}+\beta_{2} \lambda_{j}+\eta_{j}^{i} \\
\lambda_{j}^{*}=\mathbf{z}_{j}^{\prime} \gamma_{1}+\left[\pi_{j} \alpha_{j}\right] \gamma_{2}+\eta_{j}^{\lambda}
\end{gathered}
$$

where $\beta_{1}, \gamma_{1}$, and $\gamma_{2}$ are vectors of coefficients, $\mathbf{x}_{j}^{\prime}=\left[\begin{array}{ll}\hat{R} & \hat{a}\end{array}\right]$ and $\mathbf{z}_{j}^{\prime}=\left[\begin{array}{lll}\hat{R} & \hat{a} & \hat{\mu}\end{array}\right]$. Subscript refers to country $\mathrm{j}$.

\subsection{Measurement}

Below the data being used to proxy for the variables in equation (3.1) and (3.2) are described. To minimize problems of reverse causation the explanatory variables, unless otherwise noted, are measured at the start of the sample period. The sample of countries used, given in Appendix A.7., is determined by data availability. Table 1 reports summary statistics, and Appendix A.6. data sources.

Private investment, $i$. The dependent variable in equation (3.1) is private domestic investment, which is proxied with the ratio of real private domestic investment to real GDP, INVP. Unfortunately, private investment data is only 
available for the time period 1970 - 1985 and only for a limited number of countries. Therefore, in the base specification I use the ratio of real domestic investment (public plus private) to real GDP, denoted by $I N V$.

Efficiency of the legal institutions, $\lambda$. In the model, $\lambda$ is meant to capture the efficiency of the legal system or, in other words, the enforcement and specification of property rights and contracts. In previous empirical studies on growth and investment, property rights protection has been proxied with variables such as counts of revolutions, coups, assassinations, subjective indexes of civil liberties and political freedom, or some index derived from these variables. ${ }^{16}$ However, none of these variables bear direct relation to property rights protection and rent-seeking. Rather they are proxies for political conflict and social and political freedom. Knack (1993), on the other hand, employ institutional indicators not previously used in the empirical growth literature. These indicators are obtained from two private international risk services, International Country Risk Guide (ICRG), based in New York, and Business Environmental Risk Intelligence (BERI), based in Washington. The data provided by ICRG and BERI are meant to capture various dimension of the investment climate and are closely related to those institutions emphasized by North (1981) and others, captured by the parameter, $\lambda$, in the model above. ${ }^{17}$ ICRG provides five different institutional indicators for 118 countries, namely; "rule of law", "corruption in government", "quality of the bureaucracy", expropriation of private investment" and "repudiation of contracts". BERI provides four indicators for 51 countries, namely; "bureaucratic delays", "nationalization potential", "contract enforceability" and "infrastructure quality". ${ }^{18}$ The first ratings published by ICRG is from 1982, while BERI first published their scores in 1972. As in the paper by Knack (1993), and with the presumption that a single point around the middle of the sample period measures the average quality of institutions at least as well as an average value derived from the latter part of the period, initial values of the institutional indicators are summed to create two composite indexes, ICRGS and BERIS respectively. ${ }^{19}$ In the base specification, I use $I C R G S$ rather than $B E R I S$ as a proxy for $\lambda$, since ICRG provides data on more countries.

Political instability, $\pi$. In the model $\pi$ is a measure of political instability, defined as the propensity of an imminent government change. This probability is not (directly) observable. Therefore, I choose to estimate $\pi$ by means of a probit

\footnotetext{
${ }^{16}$ See for example Barro (1991) and Alesina \& Perotti (1993a).

${ }^{17}$ These data are subjective measures of the quality of institutions, representing the opinions of experts. One argument for their reliability, emphasized by Barro \& Sala-i-Martin (1994), is that clients are willing to pay substantial fees to acquire this information.

${ }^{18}$ See appendix A.4. for definitions of the different indicators.

${ }^{19}$ According to Knack (1993) both indexes are relatively stable over time.
} 
model. ${ }^{20,21}$ In a probit regression the dependent variable takes the value 1 for years in which there is a government change and a value of 0 otherwise. The explanatory variables are a subset of political, economic and structural variables designed to capture the likelihood of an imminent government change. By using pooled time-series cross-country data, I estimate the probabilities of government change over the period 1960-82. The "executive instability" index is then found by averaging the estimated probabilities of government change for each country over the relevant time period.

I use two different dependent variables. The first one, GCHANGE: government change, obtained from Jodice \& Taylor (1983), is the one used in several other studies and codes as 1 any regular or irregular transfer of executive power. The second variable, $M C H A N G E$ : major government change, obtained from Alesina et al (1992), is an attempt to eliminate government changes that do not involve a substantial turnover of leadership. That is, an attempt to distinguish between government change implying a substantial change in policy and government change that do not. Since it is political instability in polarized societies that drives the result in the model above, $M C H A N G E$ is a more appropriate measure. The explanatory variables used in the probit model are described in appendix A.5.

In the base probit specification, shown in table 2 , I use a subsample of the independent variables, actually the same as those used by Alesina et al (1992). The resulting estimated probabilities are used to create two executive instability indexes denoted by $P G O V C H 1$ and $P M A J C H 1$.

There are tow problems with these indexes. First, both indexes are likely to suffer from underreporting bias. As pointed out by Alesina et al. (1992), various events concerning political unrest, such as attempted coups and executive adjustments, are likely to be unreported in African countries implying that the measure of political instability will be underestimated with respect to these countries. Second, there are two possible sources of measurement errors in the estimated probabilities since; (i) more information than was available to the government at time $t$ is being used to derive the probability of a government change at time $t$, because pooled cross-section time series data is used, (ii) relevant information not directly observable, but available to the government, affecting the probability of a government collapse, is omitted. ${ }^{22}$

\footnotetext{
${ }^{20}$ The argument for using a probit model and estimate an instability index instead of using, for instance, the actual frequency of government change (cf. Edwards \& Tabellini (1991) and Roubini (1991)) is that, in the model, the probability of a government change rather than the actual occurrence of one is driving the result.

${ }^{21}$ In the literature two possible definitions of political instability have been proposed (see Alesina \& Perotti (1993b)). The first one, "executive instability", used in this paper, focuses on government change, i.e. on executive turnovers. The second definition, "socio-politica instability", is instead based upon indicators of social unrest and political violence.

${ }^{22}$ The possibility of measurement error are dealt with in section 3.4 .
} 
Political polarization, $\alpha$. The model also suggests that the efficiency of the property rights structure depends on political polarization captured by the parameter $\alpha$. A problem with this prediction is that it is difficult to find indexes of polarization for empirical work. However as mentioned above, one important indicator is to discriminate between the probability of government change, $P G O V C H 1$, and major government change, $P M A J C H 1$. Unlike government change, major government change is likely to capture underlying polarization in society. Thus, $P M A J C H 1$ can be seen as a composite measure of $\alpha$ and $\pi$. I also try several proxies for polarization. The first one, INCOME is the ratio between the share of total personal income before tax received by the poorest $40 \%$ to the richest $20 \%$ of the population. The presumption is that high income inequality results in polarized societies. Another proxy, meant to capture signs of polarization, is POLAR. POLAR is created by applying the method of principal components to the variables; $A S S A S S$, the number of politically motivated assassinations per million population, $D E A T H$, the number of people killed in conjunction with phenomena of domestic mass violence per million population, $E X E C U$, the number of politically motivated executions, and $D E M O C Y$ a dummy variable taking the value of 1 in democracies, 2 in countries mixing democratic and authoritarian regimes and 3 in dictatorships. The last variable is included because of reporting problems. In most dictatorships the government controls the press and restricts the diffusion of information. Hence, for propaganda reasons, measures such as $A S S A S S$ and $E X E C U$ are likely to be underreported..$^{23,24}$

Opportunity cost of investment, $R$. As a proxy for $R, I$ use the PPP value of the investment deflator in 1960, denoted by PPPI. PPPI measures the relative price of investment goods, which should have a clear effect on investment decisions. $^{25}$

Productivity and technology, $a$. In the model $a$ is a measure of the level of productivity or technology in the country. The closest empirical counterpart I can think of is $P R I M$, primary school enrollment rate in $1960 .^{26}$

Functioning of the tax system, $\mu$. The parameter $\mu$ is a measure of the wasted resources due to higher tax collection costs in the informal sector. The size of $\mu$ is

\footnotetext{
${ }^{23}$ See Alesina \& Perotti (1993a).

${ }^{24}$ There are two reasons for constructing an index by applying the method of principal components. First, it is a way to get around problems of multicollinearity and save on the degrees of freedom. Second, no one variable is likely to capture the fenomena of political polarization.

${ }^{25}$ Thus, the proxy for $R$ is not a direct measure of the opportunity cost of capital, but rather a indicator of the relative return to investments.

${ }^{26}$ The interpretation of $a$ accords well with recent growth models, such as Lucas (1988) and Rebelo (1991) that assume constant returns to a broad concept of reproducible capital (including human capital). In Romer (1990) human capital is the key input to the research sector, which generates new products and ideas that underly technological progress and economic growth. In all three models, countries with a large initial human capital stock will tend to invest more and grow faster.
} 
determined by the level of development as well as by structural variables such as the degree of urbanization in the economy and the composition of formal sector production. The proxy I use is $U R B A N$, urban population as percentage of total population in 1960 . The presumption is that tax collection costs are likely to be higher in rural areas than in urban areas.

Level of development. From the two-period model, it is not possible to draw any conclusions of the relation between private investment and level of development. However, since the model is built around a neoclassical production technology, an extension to several time periods would lead to implications for convergence. That is, poor countries grow faster and invest more than richer countries, once we control for other factors. For this reason I include the level of development proxied with real GDP per capita in $1960, G D P 60$, in some regressions. I also include GDP60 in equation (3.2) to take into account that rich countries can afford to invest more in legal infrastructure. ${ }^{27}$

Thus, in the base specification:

$$
\begin{aligned}
& \mathbf{x}_{j}^{\prime}=[P P P I P R I M] \\
& \mathbf{z}_{j}^{\prime}=[P P P I P R I M U R B A N \text { GDP60] }
\end{aligned}
$$

\subsection{Results}

Equation (3.1) and (3.2) define a recursive system. As long as the error terms are uncorrelated, least squares applied to each equation is a consistent and efficient estimator. $^{28}$ The results of OLS estimations applied to each separate equation are shown in table $3-6$. In the bench-mark specification on investment, column (3a), all variables have the right sign and are significant at the $1 \%$ level. In the base regression on property rights protection, column (3d) and (3e), both proxies for political instability, $P G O V C H 1$ and $P M A J C H 1$, also have the right sign and are significant at the $5 \%$ and $1 \%$ level respectively. As expected, the effect of major government change is much stronger. The point estimate is more than four times larger in absolute values. GDP60 and PRIM, capturing the fact that rich countries can afford to invest more in legal infrastructure, are both positive and highly significant. The coefficient on $P P P I$ is negative and significant at the $5 \%$ level in (3d) but insignificant in (3e), while $U R B A N$ has no significant effect on institutional quality. In the model, it is not possible to sign the effect of PPPI

\footnotetext{
${ }^{27}$ In a previous version of this paper, I extended the model by introducing a cost of reforming the legal system. In the extended version there is an additional effect ("asymmetry effect") that drives the result that political instability leads to poorly enforced property rights. The "asymmetry effect" arises because the government in power in period 1 fully internalizes the cost but not the benefits of reforming the legal system. The empirical prediction that arises from this extension is that initial income affects the level of investment in legal infrastructure positively.

${ }^{28}$ See appendix A.3 for a discussion on the (implicit) identifying assumptions in the empirical model.
} 
or $U R B A N$ on $I C R G S$, and it turns out that both variables are insignificantly different from zero in most specifications.

In (3b) I include GDP60 to control for convergence. The point estimate is actually positive but the coefficient is not significantly different from zero. All other variables, including ICRGS, remain significant at the $1 \%$ level. In (3c) the dependent variable is private domestic investment rather than total investment. Again as expected, the effect of property rights protection on private investment is much stronger. The coefficient is almost twice as large and highly significant $(\mathrm{t}$-statistic $=4.74)$.

In table 4, I have replaced ICRGS with $B E R I S$. The results are very similar to table 3 , except that $P G O V C H 1$ is no longer significant at the $5 \%$ level.

Summarizing the basic results, political stability is conducive to capital accumulation due to the fact that it creates necessary conditions for the government to define, enforce and protect property rights and contracts.

The model also predicts that polarization leads to less efficient legal institutions. In (5a) and (5b) INCOME is included among the regressors. In (5a) the coefficient on INCOME is positive and significant at the $5 \%$ level, i.e. the more equal distribution of income between the poorest $40 \%$ of the population and the richest $20 \%$, the stronger property rights enforcement. However in $(5 \mathrm{~b})$ this is no longer the case. The point estimate on INCOME is insignificantly different from zero. One explanation for this, as discussed in previous section, is that class conflicts and polarized political systems driven by an unequal distribution of income is already captured in the variable $P M A J C H 1$. That is, everything else equal, the probability of a major government change is higher in countries with high income inequality. This interpretation is supported by the fact that $P G O V C H 1$ becomes insignificant at the $5 \%$ level when INCOME is included among the regressors. A similar result is found in column $(5 \mathrm{c})$ and (5d). Including POLAR as a regressor, $P G O V C H 1$ is no longer significant at conventional levels. The coefficient on POLAR is significant at the $1 \%$ level in both regressions. ${ }^{29}$

Table 5 highlights an important result of the model, namely that strategic institutional reforms or lack of reforms leading to poorly enforced property rights, are limited to politically instable and polarized countries. This result accords well with those reported by Alesina et al (1992). Their findings suggest that a large propensity for major government change generates the largest effect on growth.

Another very interesting result, supporting the basic idea of this paper, is found when I include the variables for political instability and polarization in the investment equation. As shown in table $6, I C R G S$ remains significant in all different specifications, while both $P G O V C H 1, P M A J C H 1$ and the proxies for

\footnotetext{
${ }^{29}$ Logically POLAR captures not only the strategic effect of government policy in a polarized political system, but also the direct effect of socio-political disturbances on ICRGS (c.f. Alesina \& Perotti (1993a)).
} 
polarization are insignificant. A similar result is found when I include the political variables in regression (3c) with $I N V P$ as dependent variable. ${ }^{30}$ In all cases the political variables, except $P G O V C H 1$, are significant when $I C R G S$ is excluded. I infer from this that the linkage between political instability and investment indeed goes through property rights and contract enforcement as predicted by the model.

To evaluate the relative importance of the explanatory variables, I computed standardized coefficients for the independent variables. The results suggest that the proxies for property rights protection and political instability are among the most important explanatory variables. For example, for column (3c) and (3e) in table 3, the following estimates were obtained: PRIM, 0.389; PPPI, -0.231 ; ICRGS 0.571 ; GDP60, 0.301, and PRIM $0.248 ;$ PPPI, $-0.102 ;$ GDP60, 0.406 ; $U R B A N, 0.148 ; P M A J C H 1,-0.368$, respectively.

Finally, the overall fit is remarkably good: the model explains considerably more than half the variance in the dependent variables in all cases.

\subsection{Sensitivity analysis}

\subsubsection{Contemporaneous correlation}

In previous section, I pursued the econometric analysis under the null hypothesis of no contemporaneous correlation between the errors in the two equations. If this is not true, OLS yields inconsistent estimates, since the error term in equation (3.1) will be contemporaneously correlated with the regressor ICRGS ${ }^{31}$ However, testing for contemporaneous correlation using the Lagrange multiplier statistic, suggested by Breusch \& Pagan (1980), gives no support for the alternative hypothesis. For the bench-mark model the statistics are [0.15] and [1.61]. The $5 \%$ critical value from the $\chi_{(1)}^{2}$-distribution is 3.84 , implying that the null hypothesis of no contemporaneous correlation cannot be rejected. ${ }^{32}$

\subsubsection{Reverse causation}

A second possible objection to the results presented in table $3-6$ is that they could be due to reverse causation. As emphasized by Alesina \& Perotti (1993a)

\footnotetext{
${ }^{30}$ The only difference is that INCOME is also significant at the $5 \%$ level in the INVP regression. One explanation for this, is that there are other mechanisms than through property rigths protection in which income inequality can affect capital accumulation (see, for instance, Persson \& Tabellini (1991) and the references given therein).

${ }^{31}$ See appendix A.3. for a discussion on the identifying assumptions implicit in the two stage procedure of section 3.3., as well as a discussion of the test-statistics used in this section.

${ }^{32}$ If there is no contemporaneous correlation between the error terms in the two equations OLS applied to each regression is identical to SUR applied to the whole system. As can be seen from table 8, the results from SUR estimation are very similar to the bench-mark regressions using OLS. An even stronger similarity between OLS and SUR estimation is found when I replace $I N V$ with $I N V P$.
} 
and others, political instability is likely to be a function of economic conditions in the country, and possibly also of the rate of private investment. If this is the case $P M A J C H 1$ is an endogenous variable and the model should be estimated using a simultaneous equation approach. A rough test for contemporaneous correlation between the error term and ICRGS is the omitted-variable version of the Hausman test (OV-test). The result of such a test on equation (3.1) is that the null hypothesis of no contemporaneous correlation cannot be rejected at the $5 \%$ significance level.

An alternative way to deal with the problem of reverse causaltion is to jointly estimate political instability and investment. As discussed in appendix A.3., this could be done by either adding a third regression equation combining the variables $P M A J C H 1$ and $I N V$, or by using average values of the variables in the probit specification and jointly estimate the dependent variables $I N V, I C R G S$ and the actual frequency of major government change, $F R E Q M C H$.

The results of the first method with $P M A J C H 1$ as a proxy for instability is shown in table 8 . The equation combining political instability with investment is taken from Alesina \& Perotti (1993a). The signs of $I C R G S$ and PMAJCH1 are as predicted by the model, and both of them are significant at the $1 \%$ level. The point estimate of $I N V$ is not significantly different from zero, even though with the right sign, reinforcing the OV-test above. The picture is similar when polarization is proxied with INCOME instead of POLAR. In table 9 the results for the second simultaneous method are shown. Again the highly significant effects of political instability, proxied with $F R E Q M C H$, on property rights protection and of $I C R G S$ on investment continue to hold. The hypothesis of reverse causation between investment and political instability is rejected.

The results above are consistent with those reported by Alesina et al (1992). In a simultaneous time-series cross-section regression on growth and political instability they found no significant effect of growth on major government change for the period 1960-82.

\subsubsection{Measurement errors}

An important question is whether the previous findings are robust to possible measurement errors. In the bench-mark model, (3.1)-(3.2), at least two variables are likely to be measured with errors; namely $I C R G S$ and the political instability measures. However, for ICRGS in equation (3.2) the existence of measurement errors causes no statistical problem, since these errors are incorporated in the disturbance term. Moreover, since the OV-test, mentioned above, is a general test for contemporaneous correlation, it is also a test of measurement errors in $I C R G S$. An alternative way is to reestimate the model with instrumental variables. The instruments for $P G O V C H 1$ and $P M A J C H 1$ are the actual frequency of government change, $F R E Q G C H$, and major government change, $F R E Q M C H$. The results of this specification are shown in table 10 . Generally 
the results continue to hold, even though the frequency of government change is no longer significant at the $5 \%$ level.

\subsubsection{Specification} Another important question is whether the results are robust to alternative speci-
fications, and particular observations, "outliers". An examination of the residuals reveals a few outlying observations. However, dropping these countries from the sample makes no difference to the results. ${ }^{33}$

Alternative specifications of the probit model, e.g. including all explanatory variables defined in table A.5, yield results similar to those reported in table 3 . Especially the strong negative effect of major political instability on $I C R G S$ is independent of the probit specification. Including other variables in the investment equation to proxy for the variables $R$ and $a$ in the model, such as secondary school enrollment rate, $S E C 60$, and deviation from the sample mean of PPPI, $P P P I D E V$, do not change the qualitative result either. The effects of dropping the predetermined variables, $\mathbf{z}^{\prime}$, from equation (3.2) are that $P M A J C H 1$ is still highly significant, while $P G O V C H 1$ becomes insignificantly different from zero at the $5 \%$ level when $P P P I, G D P 60$ or $P R I M$ are excluded. All results continue to hold when I exclude one or two of the five ICRG indicators from ICRGS, or if I only use the ICRG-indicator "rule of law" as a proxy for $\lambda$. Moreover, including other proxies for polarization, such as ethnic and linguistic fractionalization taken from Taylor \& Hudson (1972), ETHLINF, or including more variables in the index $P O L A R$, such as number of armed attacks, ATT ACK and number of riots, RIOT, do not change the qualitative results either. ETHLINF turned out to be insignificantly different from zero at conventional levels in all specifications, while the results for POLAR generally worsen when ATT ACK and RIOT where included.

The results are also robust to alternative specifications of the sample of countries. In table 11 the estimates for non-industrialized countries are shown. The highly significant effect of political instability on institutional quality and of institutional quality on private investment continue to hold. ${ }^{34}$ Moreover, I included region specific dummies, $L A T I N, A F R I C A$ and $A S I A$, to control for cultural and political differences that might be picked up by $I C R G S$ and $P M A J C H 1$ (omitted variable test). The results are that in the investment equation, the significant positive effect of property rights protection on investment continues to hold, and only LATIN is significant at the $5 \%$ level. In the legal investment equation the political variables also remains significant, $P G O V C H 1$ on the $5 \%$ level and $P M A J C H 1$ on the $1 \%$ level. All three dummy variables are significant

\footnotetext{
${ }^{33}$ The "outliers" are Mozambique, Zambia and Uruguay for equation (3.1) and Ecuador, Iran, Iraq, Niger and Syria for equation (3.2).

${ }^{34}$ Non-industrialized countries are here defined as all non-OECD countries in the sample.
} 
at the $5 \%$ level when estimated jointly, while only $A F R I C A$ is significant when estimated individually.

\subsubsection{Generated regressors}

The political instability variables $P M A J C H 1$ and $P G O V C H 1$ are generated regressors. As such, the estimates of the standard errors may be biased. However, under the null hypothesis that the estimated coefficient of the political instability variable is zero, the standard errors are unbiased. Thus, the t statistic for the null hypothesis is not invalidated (Pagan, 1984). Unfortunately there could be a problem of interpreting the $t$ statistics for the other variables. To overcome this problem, I use average values of the variables in the probit specification and jointly estimate political instability, investment and institutional quality. The results shown in table 9 are consistent with previous findings.

\subsubsection{Heteroscedasticity}

The White (1980) test on the covariance matrix of the residuals accepts the hypothesis of no Heteroscedasticity, except for regression (3e), where I reject the hypothesis on the $5 \%$ significance level. However, when I reestimate the model using White's Heteroscedasticity-consistent estimator the results are very close to those reported in table 3 .

I conclude from the sensitivity analysis above, that the empirical results are indeed robust.

\section{Conclusion}

In a political-economy model, I have shown that it could be optimal for the government in office not to reform the legal system. The reason for this is purely strategic. A less efficient legal system promotes nonmarketable production and capital flight, and discourages domestic investment, thereby affecting the future government's tax bases. Since tax collection costs are higher in the informal sector, this will discourage the future government from collecting taxes and spending them on goods that are not valued by the current government. This strategic effect will be more pronounced in more unstable and polarized political systems.

The empirical implications of this model is that countries with instable and polarized political systems will have less efficient legal institutions, resulting in lower levels of domestic investments and higher levels of private capital outflow and nonmarketable production. These predictions hold up when confronted with cross-country data for 101 countries. Extensive sensitivity analysis shows that the empirical results are robust to an host of prospective statistical problems.

The empirical finding could have other explanations besides that advanced in this paper. Extending the model by introducing a cost of reforming the legal 
system results in an additional explanation consistent with the empirical evidence: the government in power fully internalizes the cost but not the benefit of reforming the legal system. 


\section{References}

[1] Alesina, A. and G. Tabellini, 1989, External Debt, Capital Flight and Political Risk, Journal of International Economics, 27, 199-200.

[2] Alesina, A, S. Özler, N. Roubini, and P. Swagel, 1992, Political Instability and Economic Growth, NPER wp 4173.

[3] Alesina, A. and $\mathbb{R}$. Perotti, 1993a, Income Distribution, Political Instability, and Investment, NBER wp 4486.

[4] Alesina, A. and R. Perotti, 1993b, The Politics of Growth: A Survey, mimeo, Harvard University.

[5] Barro, R., 1991, Economic Growth in a Cross Section of Countries, Quarterly Journal of Economics, May, 407-443.

[6] Barro, $\mathbb{R}$ and X. Sala-i-Martin, 1994, Economic Growth, Manuscript.

[7] Bates, R. H., 1987, Essays on the Political Economy of Rural Africa, Berkeley; CA; University of California Press.

[8] Breusch, T.S. and A.R. Pagan, 1980, The LaGrange Multiplier Test and Its Applications To Model Specifications in Econometrics, Review of Economic Studies, 47, 239-254.

[9] Cukierman, A., S. Edwards and G. Tabellini, 1992, Seigniorage and Political Instability, American Economic Review, 82, 537-556.

[10] De Soto, H., 1989, The Other Path: The Invisible Revolution in the Third World, New York: Harper and Row.

[11] Edwards, S. and G. Tabellini, 1991, Explaining Fiscal Policies and Inflation in Developing Countries, Journal of International Money and Finance, 10, S16-S48.

[12] Gelb, A., J. B. Knight and R. H. Sabot, 1991, Public Sector Employment, Rent-seeking and Economic Growth, Economic Journal, 101, 1186-1199.

[13] Hibbs, D., 1973, Mass Political Violence: A Cross-Sectional Analysis, Wiley and Sons, NY.

[14] Jodice, D. and D.L. Taylor, 1983, World Handbook of Social and Political Indicators, Yale University Press, New Haven.

[15] Judge, G.G., W.E. Griffiths, R.Carter Hill, H. Lütkepohl \& T-C Lee, 1985, The Theory and Practice of Econometrics, John Wiley and Sons.

[16] Knack, S., 1993, Institutions and the Convergence Hypothesis: The CrossNational Evidence, mimeo, IRIS. 
[17] Krueger, A. O., 1993, Political Economy of Policy Reform in Developing Countries, Cambridge, MA; MIT Press (forthcoming).

[18] Londregan, J. and K. Poole, 1990, Poverty, The Coup Trap, and the Seizure of Executive Power, World Politics, 42, 151-183.

[19] Lucas, $\mathbb{R} ., 1988$, On the Mechanism of Economic Growth, Journal of Monetary Economics 22, 3-42.

[20] Murphy, K. M., A. Shleifer and R. W. Vishny, 1991, The Allocation of Talent: Implication for Growth, Quarterly Journal of Economics, 503-530.

[21] Murphy, K. M., A. Shleifer and R. W. Vishny, 1993, Why is Rent-seeking so Costly to Growth, American Economic Review, 83, 409-414.

[22] North, D., Structure and Change in Economic History, New York, Norton 1981.

[23] Pagan, A., 1984, Econometric Issues in the Analysis of Regressions with Generated Regressors, International Economic Review, 25, 221-247.

[24] Paukert, F., 1973, Income Distribution at Different Levels of Development - A Survey of the Evidence, International Labor Review, 108, 97-125.

[25] Persson, T. and L.E.O. Svensson, 1989, Why a Stubborn Conservative Would Run a Deficit: Policy With Time-Inconsistent Preferences, Quarterly Journal of Economics, 104, 325-345.

[26] Persson, T. and G. Tabellini, 1991, Is Inequality Harmful for Growth? Theory and Evidence, American Economic Review, forthcoming.

[27] Persson, T. and G. Tabellini, 1994, Monetary and Fiscal Policy: vol. II. Politics, MIT Press, Cambridge, USA.

[28] Rebelo, S., 1991, Long-run Policy Analysis and Long-run Growth, Journal of Political Economy 99, 500-521.

[29] Romer, P., 1990, Endogenous Technological Change, Journal of Political Economy 98 , S71-S103.

[30] Roubini, N., 1991, Economic and Political Determinants of Budget Deficits in Developing Countries, Journal of International Money and Finance, 10, S49-S72.

[31] Tabellini, G. and A. Alesina, 1990, Voting on the Budget Deficit, American Economic Review, 80, 37-49.

[32] Taylor C.L. and M.C. Hudson, 1972, World Handbook of Social and Political Indicators, Yale University Press, New Haven.

[33] Tornell, A. and A. Velasco, 1992, The Tragedy of the Commons and Economic Growth: Why Does Capital Flow from Poor to Rich Countries, Journal of Political Economy, 100, 1208-1231. 
[34] UNDP , 1991, Human Development Report 1991, New York, Oxford University Press.

[35] White, H., 1980, A Heteroscedasticity-Consistent Covariance Matrix Estimator and a Direct Test for Heteroscedasticity, Econometrica, 48, 817-38.

[36] World Bank, 1988, World Development Report 1988, New York, Oxford University Press.

[37] World Bank, 1989, Sub-Saharan Africa: From Crisis to Sustainable Growth, Washington D.C. 


\section{A. Appendix}

\section{A.1. Proof of Proposition 2}

$\Lambda(1, \alpha, \mu, R, a)=0 \forall \pi, \mu, R, a$, and $\Lambda\left(\pi, \frac{1}{2}, \mu, R, a\right)=0 \forall \pi, \mu, R, a$, if and only if the first-order condition (2.21) has a corner solution for $\alpha=\frac{1}{2}$, or for $\pi=1$. Noticing that $\omega(1, \alpha)=\omega\left(\pi, \frac{1}{2}\right)=1$, the condition for statement (i) in Proposition 2 is given by;

$$
u_{c}\left(c_{2}\right) C_{\lambda}(\cdot)+Z_{\lambda}(\cdot)<0
$$

From first-order condition (2.14) we know that;

$$
u\left(c_{2}\right)=\frac{\left(i^{*}+(1-\mu) d^{*}\right)}{\left(i^{*}+d^{*}\right)}
$$

Inserting (A.2) and the expressions for $C_{\lambda}(\cdot)$ and $Z_{\lambda}(\cdot)$ from the Lemma in the firstorder condition (A.1), we get;

$$
\begin{gathered}
-\left[\frac{\left(i^{*}+(1-\mu) d^{*}\right)}{\left(i^{*}+d^{*}\right)}\right]\left[T_{\lambda}(\cdot) R\left(i^{*}+d^{*}\right)\right]+T_{\lambda}(\cdot) R\left(i^{*}+(1-\mu) d^{*}\right)+\tau^{*} R \mu I_{\lambda}(\cdot) \\
=\tau^{*} R \mu I_{\lambda}(\cdot)<0
\end{gathered}
$$

since $I_{\lambda}(\cdot)<0$. Applying the implicit function theorem to the first-order condition (2.21), and noticing that $\lambda^{*}>0$, implies that $\alpha \in\left(0, \frac{1}{2}\right)$, and $\pi \in[0,1)$, gives;

$$
\begin{aligned}
\frac{d \Lambda(\cdot)}{d \pi} & =-\frac{\omega_{\pi}(\pi, \alpha) Z_{\lambda}(\cdot)}{S . O . C .}<0 \\
\frac{\Lambda(\cdot)}{d \alpha} & =-\frac{\omega_{\alpha}(\pi, \alpha) Z_{\lambda}(\cdot)}{\text { S.O.C. }}<0
\end{aligned}
$$

since $\omega_{\pi}(\pi, \alpha)=\frac{(1-2 \alpha)}{(1-\alpha)}>0$, and $\omega_{\alpha}(\pi, \alpha)=\frac{(1-\pi)}{(1-\alpha)^{2}}>0$.

The fourth statement in Proposition 2 follows from (A.4), (A.5), and the fact that;

$$
\lim _{\substack{\alpha \rightarrow 0 \\ \pi \rightarrow 0}} \omega(\pi, \alpha)=0
$$

Thus, the first-order condition (2.21) must bind for some $\pi>0$, and $\alpha>0$.

Finally, using the implicit function theorem on (2.21), it is possible to show that;

$$
\Lambda_{\mu}(\cdot) \gtrless 0, \Lambda_{R}(\cdot) \gtrless 0, \Lambda_{a}(\cdot) \gtrless 0
$$

\section{A.2. From the model to testable hypotheses}

Assume that $a, R$ and $\mu$ differ randomly across countries according to;

$$
\begin{array}{r}
R_{j}=\hat{R}_{j}+\varepsilon_{j}^{R} \\
a_{j}=\hat{a}_{j}+\varepsilon_{j}^{a}
\end{array}
$$




$$
\mu_{j}=\hat{\mu}_{j}+\varepsilon_{j}^{\mu}
$$

where $\varepsilon_{j}^{R}, \varepsilon_{j}^{a}, \varepsilon_{j}^{\mu}$ are $i i d$ error terms, and the subscript refers to country j. $\hat{R}_{j}, \hat{a}_{j}, \hat{\mu}_{j}$ are observable values of $R_{j}, a_{j}$ and $\mu_{j}$ respectively.

Linear approximations of (2.10) and (2.22) around the points $\lambda=0, R=R_{0}, a=$ $a_{0}$ and $\pi=1, \alpha=\frac{1}{2}, R=R_{0}, a=a_{o}, \mu=\mu_{0}$ respectively, using (A.7)-(A.9) and ignoring country subscripts give;

$$
\begin{gathered}
i^{*}=\beta_{0}+\beta_{\lambda} \lambda+\beta_{R} \hat{R}+\beta_{a} \hat{a}+\eta^{i} \\
\lambda^{*}=\gamma_{0}+\gamma_{\pi} \pi+\gamma_{\alpha} \alpha+\gamma_{\mu} \hat{\mu}+\gamma_{R} \hat{R}+\gamma_{a} \hat{a}+\eta^{\lambda}
\end{gathered}
$$

where:

$$
\begin{gathered}
\alpha_{0}=I(\cdot)-I_{a}(\cdot) a_{0}-I_{R}(\cdot) R_{0}, \beta_{\lambda}=I_{\lambda}(\cdot), \beta_{R}=I_{R}(\cdot), \beta_{a}=I_{a}(\cdot) \\
\gamma_{0}=\Lambda(\cdot)-\Lambda_{\pi}(\cdot)-\Lambda_{\alpha}(\cdot) \frac{1}{2}-\Lambda_{\mu}(\cdot) \mu_{0}-\Lambda_{R}(\cdot) R_{0}-\Lambda_{a}(\cdot) a_{0}, \gamma_{\pi}=\Lambda_{\pi}(\cdot) \\
\gamma_{\alpha}=\Lambda_{\alpha}(\cdot), \gamma_{\mu}=\Lambda_{\mu}(\cdot), \gamma_{R}=\Lambda_{R}(\cdot), \gamma_{a}=\Lambda_{a}(\cdot), \eta^{i}=I_{R}(\cdot) \varepsilon^{R}+I_{a}(\cdot) \varepsilon^{a} \\
\eta^{\lambda}=\Lambda_{\mu}(\cdot) \varepsilon^{\mu}+\Lambda_{R}(\cdot) \varepsilon^{R}+\Lambda_{a}(\cdot) \varepsilon^{a}
\end{gathered}
$$

The error term $\eta^{i}$ captures the effects on investment of country-specific variations in the (unobservable) level of $R$ and $a$, while the error term $\eta^{\lambda}$ captures the effects on the efficiency of the legal system of country-specific variations in the (unobservable) level of $R, a$ and $\mu$. If the assumption of the process for $R$ and $a$ are correct, the error terms in the two equations are contemporaneously correlated. This is tested for in section 3.4 .

\section{A.3. Identifying assumptions}

This appendix outlines the identifying assumptions implicit in the two stage procedure of section 3.3, as well as the test statistics used in section 3.4. From the model the following testable system for country $\mathbf{j}$ can be derived;

$$
\begin{aligned}
& i_{j}=\mathbf{x}_{i}^{\prime} \beta_{1}+\beta_{2} \lambda_{j}+\eta_{j}^{i} \\
& \lambda_{j}=\mathbf{z}_{j}^{\prime} \gamma_{1}+\gamma_{2} \pi_{j}+\eta_{j}^{\lambda}
\end{aligned}
$$

where $\beta_{1}$ and $\gamma_{1}$ are vectors of coefficients. To avoid problems of reverse causality the explanatory variables in vectors $\mathbf{x}_{j}^{\prime}$ and $\mathbf{z}_{j}^{\prime}$ are measured at the beginning of the sample period. The problem with this set up is that $\pi$, the probability of an imminent government change, is not observable. I choose to deal with this problem through a two stage procedure. In the first stage I assume that $\pi_{j}$ can be estimated using a probit model on pooled time series cross section data. Hence;

$$
\pi_{j t}=\operatorname{probit}\left[y_{j t}=\mathbf{u}_{j t-1}^{\prime} \theta+\nu_{j t} \mid t=1960-82\right]
$$

The interpretation of (A.14) is that a government change a time $t, y_{j t}$, is triggered by a specific realization of the explanatory variables, $\mathbf{u}_{j t-1}$, or the error term $\nu_{j t}$. Investment is not included among the explanatory variables, $\mathbf{u}_{j t-1}$. Consequently, I assume that there is no feedback from the level of investment to the probability of government 
change. Furthermore, $\mathrm{I}$ assume that $\nu_{j t}$ as well as $\mathbf{u}_{j t-1}$ are uncorrelated with the error terms $\eta_{j}^{i}$ and $\eta_{j}^{\lambda}$.

By estimating the vector of coefficients $\theta$ with a probit model, I obtain $\hat{\pi}_{j t}$. Define $\hat{\pi}_{j}$ as the average value of $\hat{\pi}_{j t}$ during the sample period, I have that $\hat{\pi}_{j}$ is a complicated nonlinear function given by;

$$
\hat{\pi}_{j}=F\left[\mathbf{u}_{j t-1}, y_{j t}, \nu_{j t} \mid t=1960-82\right]
$$

Substituting $\hat{\pi}_{j}$ for $\pi_{j}$ in equation (A.13) we get;

$$
\lambda_{j}=\mathbf{z}_{j}^{\prime} \gamma_{1}+\gamma_{2} \hat{\pi}_{j}+\eta_{j}^{\lambda}
$$

OLS applied to equation (A.12) and (A.16) separately is a consistent and efficient estimator as long as the assumption of no correlation between $\eta_{j}^{\lambda}$ and $\hat{\pi}_{j}$ holds and $\mathrm{E}\left[\eta_{j}^{i} \eta_{j}^{\lambda}\right]=0$, that is no contemporaneous correlation between the disturbances in the two equation.

If the last assumption no longer holds, there will be contemporaneous correlation between $\eta_{j}^{i}$ and $\lambda$, implying that OLS is an inconsistent estimator. I can test for contemporaneous correlation between the two equations using the Langrange multiplier statistic, suggested by Breusch \& Pagan (1980). ${ }^{35}$ The Langrange multiplier statistic can be derived using the SUR estimator. Defining the following "aggregate model";

$$
\left[\begin{array}{l}
\mathrm{i} \\
\lambda
\end{array}\right]=\left[\begin{array}{cc}
\mathbf{X} & 0 \\
0 & \mathbf{Z}
\end{array}\right]\left[\begin{array}{l}
\beta_{1} \\
\gamma_{1}
\end{array}\right]+\left[\begin{array}{ll}
\lambda & 0 \\
0 & \hat{\pi}
\end{array}\right]\left[\begin{array}{l}
\beta_{2} \\
\gamma_{2}
\end{array}\right]+\left[\begin{array}{l}
\eta_{j}^{i} \\
\eta_{j}^{\lambda}
\end{array}\right]
$$

The SUR estimator, $\mathbf{b}^{S U R}=\left[X^{\prime}\left(\hat{\Sigma}^{-1} \otimes I\right) X\right]^{-1} X^{\prime}\left(\hat{\Sigma}^{-1} \otimes I\right) \mathbf{y}$, is the estimated generalized least squares estimator of the "aggregate model", where:

$$
X=\left[\begin{array}{cc}
\mathbf{X} & 0 \\
0 & \mathbf{Z}
\end{array}\right] \text { and } \mathbf{y}=\left[\begin{array}{c}
i \\
\lambda
\end{array}\right]
$$

and the estimated covariance matrix for the complete error vector is given by;

$$
\Phi=\left[\begin{array}{ll}
\hat{\sigma}_{11} I_{T} & \hat{\sigma}_{12} I_{T} \\
\hat{\sigma}_{21} I_{T} & \hat{\sigma}_{22} I_{T}
\end{array}\right]=\hat{\Sigma} \otimes I_{T}
$$

The Lagrange multiplier statistic, $\lambda_{L M}$, is in the two equation case given by;

$$
\lambda_{L M}=T \frac{\hat{\sigma}_{21}^{2}}{\hat{\sigma}_{11} \hat{\sigma}_{22}}
$$

Under $\mathrm{H}_{0}$ of no contemporaneous correlation $\left(\hat{\sigma}_{i j}=0\right), \lambda_{L M}$ has an asymptotic $\chi^{2}$ distribution with 1 degree of freedom. If $\hat{\sigma}_{i j}=0$ then $\mathbf{b}^{O L S}=\mathbf{b}^{S U R} \cdot{ }^{36}$

\footnotetext{
${ }^{35}$ See Judge et al. (1985)

${ }^{36}$ Rewriting $\mathbf{b}^{S U R}$ in detail, using the fact that $\sigma_{i j}=0$, we get in the two equation case that;

$$
\mathbf{b}^{S U R}=\left[\begin{array}{c}
\mathbf{b}_{1}^{S U R} \\
\mathbf{b}_{2}^{S U R}
\end{array}\right]=\left[\begin{array}{cc}
\hat{\sigma}_{11} X^{\prime} X & \hat{\sigma}_{12} X^{\prime} Z \\
\hat{\sigma}_{21} Z^{\prime} X & \hat{\sigma}_{22} Z^{\prime} Z
\end{array}\right]^{-1}\left[\begin{array}{cc}
\hat{\sigma}_{11} X^{\prime} \mathbf{i} & \hat{\sigma}_{12} X^{\prime} \lambda \\
\hat{\sigma}_{21} Z^{\prime} \lambda & \hat{\sigma}_{22} Z^{\prime} \mathbf{i}
\end{array}\right]=
$$
}


A similar problem with respect to the OLS estimator will occur if $\hat{\pi}_{j}$ is a function of $i_{j}$. In that case there will be contemporaneous correlation between the disturbance and the regressor in both regressions, implying that neither OLS nor SUR are consistent estimators. A rough test for joint endogeneity (contemporaneous correlation) is the omitted variable, $\mathrm{OV}$, version of the Hausman test. ${ }^{37}$ To perform the OV test I estimate the following reduced form;

$$
\lambda_{j}=\mathrm{v}_{j}^{\prime} \chi+\varepsilon_{j}
$$

where $\mathbf{v}_{j}^{\prime}$ is a vector of all exogenous variables in the system (i.e. $x_{j}^{\prime}$ and $z_{j}^{\prime}$ ). Estimation of (A.21) gives;

$$
\hat{\lambda}_{j}=\mathrm{v}_{j}^{\prime} \hat{\chi} \quad \text { or } \quad \lambda_{j}=\hat{\lambda}_{j}+\hat{\varepsilon}_{j}
$$

Define the following regression equation;

$$
i_{j}=\mathbf{x}_{j}^{\prime} \beta_{1}+\beta_{2} \hat{\lambda}_{j}+\zeta \hat{\varepsilon}_{j}+\eta_{j}^{i}
$$

Under the null hypothesis of no simultaneity, the correlation between $\hat{\varepsilon}_{j}$ and the error term will go to zero. Thus, when $\mathrm{H}_{\mathbf{0}}$ holds, OLS will be a consistent estimator and as $\zeta$ is equal to $\beta_{2}$ by construction, the OV test is given by rewriting (A.23);

$$
i_{j}=\mathbf{x}_{j}^{\prime} \beta_{1}+\beta_{2} \lambda_{j}+\left(\zeta-\beta_{2}\right) \hat{\varepsilon}_{j}+\eta_{j}
$$

Under the null hypothesis $\zeta=\beta_{2}$, so that the coefficient on $\hat{\varepsilon}_{j}$ should equal 0 . Thus, a test for simultaneity is a test on the coefficient of $\hat{\varepsilon}_{j}$ to equal zero. ${ }^{38}$

Another way to cope with the problem of reverse causation is to jointly estimate political instability and investment along the lines of Londegran \& Poole (1988) and Alesina et al. (1992). As I do not have time series data on investment or institutional quality, and as political instability also is a function of more slowly changing features, such as culture, tradition and possible cleavages within society, a joint estimation must be carried out on cross section data only, as in Alesina \& Perotti (1993a,b).

There are two alternative ways of jointly estimating political instability and investment. The first method is to simply include a third linear equation combining the variables $i$ and $\hat{\pi}$. However, this is a problematic approach. First, in the model there is no feedback from the economic outcome and the political system since $\pi$ is exogenous.

$$
\begin{gathered}
=\left[\begin{array}{cc}
\hat{\sigma}_{11} X^{\prime} X & 0 \\
0 & \hat{\sigma}_{22} Z^{\prime} Z
\end{array}\right]^{-1}\left[\begin{array}{cc}
\hat{\sigma}_{11} X^{\prime} \mathbf{y}_{1} & 0 \\
0 & \hat{\sigma}_{22} Z^{\prime} \mathbf{y}_{2}
\end{array}\right]= \\
=\left[\begin{array}{c}
\left(X^{\prime} X\right)^{-1} X \mathbf{i} \\
\left(Z^{\prime} Z\right)^{-1} X \lambda
\end{array}\right]=\left[\begin{array}{l}
\mathbf{b}_{1}^{O L S} \\
\mathbf{b}_{2}^{O L S}
\end{array}\right]
\end{gathered}
$$

${ }^{37}$ Note, however, that the OV test is not a specific test for endogeinity/exogeinity, but a more general test for contemporaneous correlation between the regressors and the disturbance term.

${ }^{38}$ The intuition behind the OV-test is straightforward. Without $\hat{\varepsilon}_{j}$ in (A.24) the regression would produce residuals $\hat{\eta}_{j}^{i}$. If $\hat{\varepsilon}_{j}$ is to have a nonzero coefficient, it must "take" some explanatory power from $\hat{\eta}_{j}^{i}$, implying that if $\left(\zeta-\beta_{2}\right) \neq 0, \hat{\eta}_{j}^{i}$ and $\hat{\varepsilon}_{j}$ are correlated. Since $\lambda_{j}=\hat{\lambda}_{j}+\hat{\varepsilon}_{j}$, a test of the coefficient on $\hat{\varepsilon}_{j}$, is a test for contemporaneous correlation between the regressor $\lambda_{j}$ and the error term $\eta_{j}^{i}$. 
Second, it could be argued that the explanatory variables used to explain $\hat{\pi}$ should be included in the probit specification. Third, several political scientists argue that the relation between political instability and economic performance is nonlinear. ${ }^{39}$ Finally it is not clear if the feedback is from $i$ to $\pi$ or from $\lambda$ to $\pi$ or both. Keeping this caveats in mind and following Alesina \& Perotti (1993), the equation that connects the economic variables with political instability is specified as;

$$
\hat{\pi}_{j}=\mathrm{w}_{j}^{\prime} \delta_{1}+\delta_{2} i_{j}+\eta_{j}^{\pi}
$$

where $\delta_{1}$ is a vector of coefficients and;

$$
\mathrm{w}^{\prime}=[C \text { GDP60 POLAR INCOME URBAN LATIN AFRICA] }
$$

In (A.25) investment is included to take into account the inverse relationship between political instability and investment. The hypothesis is that growing economies, proxied with $i$, tend to be more stable, so that $\delta_{2}<0$. Income per capita at the beginning of the period, GDP60, as well as the education proxy PRIM, are also include. The presumption is that rich countries are more stable than poor countries. ${ }^{40}$ As discussed in Alesina \& Perotti (1993a), income inequality as well as other socio-political cleavages, by fueling social discontent, increases political instability. Consequently I expect the coefficients on POLAR and INCOME to be negative. I also include a variable for urbanization. The predominant view in the political science literature is that more urbanized societies will be more unstable because political participation and social unrest are likely to be higher in cities. ${ }^{41}$ Finally, I include two regional specific dummies, $L A T I N$ for Latin America and AFRICA for Africa, to capture region-specific cultural factors. Thus, the simultaneous system is specified as; ${ }^{42}$

$$
\begin{aligned}
& i_{j}=\mathbf{x}_{i}^{\prime} \beta_{1}+\beta_{2} \lambda_{j}+\eta_{j}^{i} \\
& \lambda_{j}=\mathbf{q}_{j}^{\prime} \gamma_{1}+\gamma_{2} \hat{\pi}_{j}+\eta_{j}^{\lambda} \\
& \hat{\pi}_{j}=\mathbf{w}_{j}^{\prime} \delta_{1}+\delta_{2} i_{j}+\eta_{j}^{\pi}
\end{aligned}
$$

where $\beta_{1}$ and $\gamma_{1}$ are vectors of coefficients and;

$$
\begin{gathered}
\mathbf{x}^{\prime}=\left[\begin{array}{l}
C P R I M \\
\mathbf{q}^{\prime}=[C P P I
\end{array}\right] \\
\text { C POLAR INCOME GDP60 PRIM URBAN PPPI }]
\end{gathered}
$$

The second method is to use average values of the variables in the probit specification, instead of a two stage procedure, and simultaneously estimate $i, \lambda$ and the actual frequency of major government change, $F R E Q M C H$. This method has the advantage of yielding consistent estimates of the standard errors. The major drawback is that

\footnotetext{
${ }^{39}$ See Hibbs (1973) and the references given therein.

${ }^{40}$ See Londregan \& Poole (1990) for references on this issue, and especially on the relation between poverty and coups.

${ }^{41}$ See for example Hibbs (1973).

${ }^{42} \mathrm{By}$ the order condition, all three equations are overidentified.
} 
information contained in the time-series is lost. Thus, the second simultaneous model is given by (A.27) and; ${ }^{43}$

$$
\begin{gathered}
\lambda_{j}=\mathrm{z}_{j}^{\prime} \gamma_{1}+\phi_{2} F R E Q M C H_{j}+\eta_{j}^{\lambda} \\
F R E Q M C H_{j}=\mathrm{s}_{j}^{\prime} \varphi_{1}+\varphi_{2} i_{j}+\eta_{j}^{F R}
\end{gathered}
$$

where $\gamma_{1}$ and $\varphi_{1}$ are vectors of coefficients and;

$$
\mathrm{s}^{\prime}=[A T T M A V \text { REPRAV EX ADJAV GR5981AV LATIN AFRICA] }
$$

\section{A.4. Definitions of Institutional Indicators}

\section{International Country Risk Guide (ICRG) ${ }^{44}$}

Rule of law: This variable "reflects the degree to which the citizens of a country are willing to accept the established institutions to make and implement laws and adjudicate disputes". Higher scores indicate "sound political institution, a strong court system, and provision for an orderly succession of power". Original variable name in ICRG is "law and order tradition". Scored 0-6.

Corruption in Government: Lower scores indicate "high government officials are likely to demand special payments" and "illegal payments are generally expected throughout lower levels of government" in the form of "bribes connected with import and export licenses, exchange controls, tax assessment, police protection or loans". Scored 0-6.

Quality of the Bureaucracy: High scores indicate "autonomy from political pressure" and "strength and experience to govern without drastic changes in policy or interruptions in government services", also "existence of an "established mechanism for recruiting and training". Scored 0-6.

Expropriation of Private Investment: Assessment of risk of "outright confiscation" or "forced nationalization". Scored 0-10, with lower scores for higher risks.

Repudiation of Contracts by Government: Indicates the "risk of a modification in a contract taking the form of repudiation, postponement, or scaling down" due to "budget cutbacks, indigenization pressure, a change in government, or a change in government economic and official priorities". Scored 0-10, with lower scores for higher risks.

$I C R G S=$ Sum of the five preceding variables, with the first three "normalized" into 10-point scales

\section{Business Environmental Risk Intelligence (BERI)}

Bureaucratic Delays: Measures the "speed and efficiency of the civil service including processing customs clearances, foreign exchange remittances and similar applications". Scored 1-4, with higher scores for greater efficiency.

Nationalization potential: Defined as "the range between expropriation for no compensation and preferential treatment for nationals". Scored 1-4, with higher scores for lower risks.

Contract Enforceability: Measures the "relative degree to which contractual agreements are honored". Scored 1-4, with higher scores for greater enforceability.

\footnotetext{
${ }^{43} \mathrm{By}$ the order condition, all three equations are overidentified.

${ }^{44}$ The definitons are taken from Knack (1993).
} 
Infrastructure Quality: Assesses "facilities for and ease of communications between headquarters and the operation within the country", as well as "quality of transportation". Scored 1-4, with higher scores for superior quality.

$B E R I S$ : Sum of the preceding four variables.

\section{A.5. Variables used in the probit model of government change}

Dependent variables

GCHANGE = Government change. Dummy variable taking the value of one each year in which there is a change in executive leadership, i.e. either a coup or a regular government transfer, and zero otherwise. [Source: Alesina et al (1992) from Jodice \& Taylor (1983)].

MCHANGE = Major government change. Dummy variable taking the value of one each year in which there is a major change in executive leadership, i.e. either a coup or a major regular government transfer, and zero otherwise. [Source: Alesina et al (1992)] Explanatory variables:

Economic variables:

GRGDP = Annual growth of real per capita GDP. [Source: Alesina et al. (1992) constructed from Summers \& Heston (1988)]

GDP = Log of real per capita GDP. [Source: Alesina et al. (1992) constructed from Summers \& Heston (1988)]

Political variables:

EXADJ = Executive adjustment. Dummy variable taking the value of one in years which there is a change in the composition of the executive not resulting in a government transfer, and a value zero otherwise. [Source: Jodice \& Taylor (1983)]

ATTM = Attempt. Dummy variable taking the value of one in years which there is an unsuccessful attempt at changing the government, and a value zero otherwise. [Source: Jodice \& Taylor (1983)]

REPR = Repression. Government imposed sanctions to neutralize, suppress or eliminate perceived threat to the security of the government or the regime. [Source: Jodice \& Taylor (1983)]

Structural variables:

DEMOCY $=$ Democracy. Democracy variable taking the value of 1 in democratic regimes, 2 for regimes mixing democratic and authoritarian features, and 3 for authoritarian regimes. [Source: Alesina et al. (1992)]

LATIN = Dummy variable for South and Latin America.

AFRICA = Dummy variable for Africa.

A variable followed by a number 1 , indicates that the variable is lagged one period.

\section{A.6. Variable definitions}

INV = Average from 1960 to 1985 of the ratio of real domestic investment (private plus public) to real GDP. [Source: Barro \& Wolf (1989)].

$\mathrm{INVP}=$ Average from 1970 to 1985 of the ratio of real private domestic investment to 
real GDP. [Source: Barro \& Wolf (1989)].

ICRGS = Index of institutional quality, defined in appendix A.4.

BERIS = Index of institutional quality, defined in appendix A.4.

PGOVCH1 = Measure of political instability, defined in appendix A.5 and table 2.

PMAJCH1 = Measure of political instability, defined in appendix A.5 and table 2.

PRIM = 1960 primary-school enrollment rate. [Source: Barro \& Wolf (1989)].

PPPI $=1960$ PPP value of the investment deflator (U.S. $=1.0)$. [Source: Barro \& Wolf (1989)].

GDP60 = 1960 value of real per capita GDP (1980 base year). [Source: Barro \& Wolf (1989)].

URBAN = Urban population as a percentage of total population in 1960. [Source:

Human Development Report, 1991]

INCOME = The ratio between the share of total income before tax received by the poorest $40 \%$ and the richest $20 \%$ of the population, around 1960. [Source: Paukert (1973)].

POLAR = Index created by applying the method of principal components to the variables; ASSASS, the number of politically motivated assassinations per million population, average 1960-85 (or subsample) [Source: Barro \& Wolf (1989)], DEATH; the number of people killed in conjunction with phenomena of domestic mass violence per million population, average 1960-77 [Source: Jodice \& Taylor (1983)], EXECU; the number of politically motivated executions, average 1960-82 [Source: Jodice \& Taylor (1983)] and DEMOCY a dummy variable taking the value of 1 in democracies, 2 in countries mixing democratic and authoritarian features and 3 in dictatorships, average 1960-82 [Source: Alesina et al. (1992)].

LATIN = Dummy variable for South and Latin America.

AFRICA = Dummy variable for Africa.

FREQGCH = Average frequency of government change from 1960-82. [Source: Constructed from Alesina et al. (1992)].

FREQMCH = Average frequency of major government change from 1960-82. [Source:

Constructed from Alesina et al. (1992)].

PPPIDEV = Magnitude of the deviation of PPPI from the sample mean in 1960.

[Source: Constructed from Barro \& Wolf (1989)].

SEC60 = 1960 secondary-school enrollment rate. [Source: Barro \& Wolf (1989)].

ETHLINF = Ethnic and linguistic fractionalization around 1960. [Source: Taylor \& Hudson (1972)].

ATTACK $=$ the number of armed attacks, average 1960-82 [Source: Jodice \& Taylor (1983)].

RIOT $=$ the number of riots, average 1960-82 [Source: Jodice \& Taylor (1983)].

ATTMAV = Average from 1959-81 of ATTM, defined in appendix A.5.

REPRAV = Average from 1959-81 of REPR, defined in appendix A.5.

EXADJAV = Average from 1959-81 of EXADJ, defined in appendix A.5.

GR5981 = Average from 1959-81 of GRGDP, defined in appendix A.5. 
A.7. Sample of countries

\begin{tabular}{|c|c|c|c|}
\hline Algeria & Angola & Argentina* & Australia* \\
\hline Austria* & Bangladesh & Belgium* & Bolivia* \\
\hline Botswana* & Brazil* & Cameroon* & Canada* \\
\hline Chile* & Colombia* & Congo & Costa Rica* \\
\hline Cote d'Ivoire & Cyprus* & Denmark* & Dominican Rep* \\
\hline Ecuador* & Egypt* & El Salvador* & Ethiopia \\
\hline Finland ${ }^{*}$ & France ${ }^{*}$ & Gabon & Gambia \\
\hline Germany (West)* & Ghana* & Greece $^{*}$ & Guatemala* \\
\hline Guinea & Haiti & Honduras & Hong Kong \\
\hline Iceland* & India* & Indonesia & $\operatorname{Iran}^{*}$ \\
\hline Iraq & Ireland* & Israel* $^{*}$ & Italy* \\
\hline Jamaica & Japan* & Jordan* & Kenya* \\
\hline Korea (South)* & Liberia* & Luxembourg* & Madagascar \\
\hline Malawi* & Malaysia* & Mali & Malta* \\
\hline Mexico* & Marocco* & Mozambique & Netherlands* \\
\hline New Zeeland* & Nicaragua* & Niger & Nigeria \\
\hline Norway* & Pakistan* & Panama* & Papua New Guinea* \\
\hline Paraguay* & Peru* & Philippines* & Portugal \\
\hline Saudi Arabia & Senegal* & Sierra Leone* & Singapore* \\
\hline Somalia & South Africa* & Spain* & Sri Lanka* \\
\hline Sudan & Sweden* & Switzerland* & Syria \\
\hline Taiwan* & Tanzania & Thailand* & Togo \\
\hline Trinidad Tobago & Tunisia* & Turkey* & Uganda* \\
\hline United Kingdom* & United States* & Uruguay* & Venezuela* \\
\hline Zaire* & Zambia* & Zimbabwe & Burma* \\
\hline Guyana* & & & \\
\hline
\end{tabular}


Table 1

SUMMARY STATISTICS FOR THE SAMPLE

\begin{tabular}{lccccc}
\hline \hline & NOBS & MEAN & STDEV & MIN & MAX \\
\hline ICRGS & 101 & 27.82 & 12.97 & 8.00 & 50.0 \\
BERIS & 49 & 9.45 & 2.99 & 3.00 & 14.8 \\
INV & 101 & 0.188 & 0.079 & 0.042 & 0.369 \\
INVP & 72 & 0.177 & 0.070 & 0.029 & 0.364 \\
PMAJCH1 & 101 & 0.114 & 0.027 & 0.069 & 0.189 \\
PGOVCH1 & 101 & 0.288 & 0.066 & 0.127 & 0.392 \\
PRIM & 101 & 0.755 & 0.332 & 0.05 & 1.44 \\
PPPI & 101 & 0.746 & 0.337 & 0.254 & 2.58 \\
URBAN & 101 & 37.2 & 24.9 & 2.00 & 100.0 \\
GDP60 & 101 & 1.91 & 1.81 & 0.208 & 7.38 \\
POLAR & 98 & 0.0 & 1.0 & -1.07 & 5.91 \\
INCOME & 49 & 0.286 & 0.124 & 0.101 & 0.639 \\
FREQGCH & 101 & 0.291 & 0.151 & 0.0 & 0.799 \\
FREQMCH & 101 & 0.114 & 0.089 & 0.0 & 0.391 \\
\hline
\end{tabular}

CORRELATION MATRIX

\begin{tabular}{lrrrrrr}
\hline \hline & INV & INVP & ICRGS & BERIS & GDP60 & PMAJCH1 \\
INVP & 0.929 & & & & & \\
ICRGS & 0.597 & 0.672 & & & & \\
BERIS & 0.630 & 0.603 & 0.847 & & & \\
GDP60 & 0.489 & 0.418 & 0.703 & 0.747 & & \\
PMAJCH1 & -0.205 & -0.363 & -0.386 & -0.497 & -0.075 & \\
PGOVCH1 & 0.432 & 0.405 & 0.385 & 0.378 & 0.538 & 0.018 \\
PRIM & 0.638 & 0.607 & 0.610 & 0.649 & 0.613 & 0.014 \\
PPPI & -0.390 & -0.412 & -0.169 & -0.047 & -0.072 & -0.029 \\
URBAN & 0.542 & 0.447 & 0.619 & 0.634 & 0.743 & 0.036 \\
POLAR & -0.454 & -0.499 & -0.626 & -0.571 & -0.448 & 0.199 \\
INCOME & 0.277 & 0.373 & 0.300 & 0.304 & 0.187 & -0.281 \\
FREQGCH & 0.266 & 0.369 & 0.186 & 0.129 & 0.301 & 0.145 \\
FREQMCH & 0.008 & -0.107 & -0.104 & -0.168 & 0.017 & 0.452 \\
\hline & PGOVCH1 & PRIM & PPPI & URB & POLAR & INCOME \\
PRIM & 0.615 & & & & & \\
PPPI & -0.356 & -0.142 & & & & \\
URBAN & 0.591 & 0.701 & -0.089 & & & \\
POLAR & -0.203 & -0.441 & 0.173 & -0.370 & & \\
INCOME & 0.370 & 0.118 & 0.007 & 0.158 & -0.274 & \\
FREQGCH & 0.625 & 0.382 & -0.104 & 0.327 & -0.062 & 0.126 \\
FREQMCH & 0.160 & 0.119 & -0.010 & 0.112 & 0.048 & -0.006 \\
\hline
\end{tabular}


Table 2

Probit Model of Government Change, 1960-82.

\begin{tabular}{lll}
\hline \hline Expl.var. & $\begin{array}{l}\text { GCHANGE } \\
(2 \mathrm{a})\end{array}$ & $\begin{array}{l}\text { MCHANGE } \\
(2 \mathrm{~b})\end{array}$ \\
\hline Constant & $\begin{array}{l}-0.553 \\
(-10.43)\end{array}$ & $\begin{array}{l}-1.378 \\
(-20.91)\end{array}$ \\
& -1.359 & -1.809 \\
GRGDP1 & $(-3.511)$ & $(-3.820)$ \\
& 0.317 & \\
GCHANG1 & $(5.548)$ & \\
& & 0.162 \\
MCHANG1 & & $(1.654)$ \\
& & 0.209 \\
EXADJ1 & 0.140 & $(3.181)$ \\
& $(2.650)$ & 0.019 \\
AFRICA & -0.398 & $(0.253)$ \\
& $(-6.466)$ & 0.267 \\
LATIN & -0.138 & $(3.239)$ \\
\hline no. obs. & $(-2.018)$ & 2689 \\
Log Likelihood & -1547.5 & -925.0 \\
\hline
\end{tabular}

Note: Probit estimation, t-statistics in parentheses. The average estimated probabilities of a government change from these regressions are used to create the indexes PGOVCH1 and PMAJCH1. 


\section{Table 3}

Cross-section regressions on investment and institutional quality: Base specification

\begin{tabular}{|c|c|c|c|c|c|}
\hline Expl.var. & $\begin{array}{l}\text { INV } \\
(3 a)\end{array}$ & $\begin{array}{l}\text { INV } \\
(3 \mathrm{~b}) \\
\end{array}$ & $\begin{array}{l}\text { INVP } \\
\text { (3c) }\end{array}$ & $\begin{array}{l}\text { ICRGS } \\
(3 \mathrm{~d})\end{array}$ & $\begin{array}{l}\text { ICRGS } \\
(3 \mathrm{e}) \\
\end{array}$ \\
\hline Constant & $\begin{array}{l}0.113^{* *} \\
(0.020)\end{array}$ & $\begin{array}{l}0.114^{* *} \\
(0.021)\end{array}$ & $\begin{array}{l}0.055^{*} \\
(0.025)\end{array}$ & $\begin{array}{l}25.83^{* *} \\
(5.604)\end{array}$ & $\begin{array}{l}35.44^{* *} \\
(4.175)\end{array}$ \\
\hline ICRGS & $\begin{array}{l}0.18 \mathrm{E}-2^{* *} \\
(0.52 \mathrm{E}-3)\end{array}$ & $\begin{array}{l}0.17 \mathrm{E}-2^{* *} \\
(0.62 \mathrm{E}-3)\end{array}$ & $\begin{array}{l}0.31 \mathrm{E}-2^{* *} \\
(0.66 \mathrm{E}-3)\end{array}$ & & \\
\hline PRIM & $\begin{array}{l}0.099^{* *} \\
(0.020)\end{array}$ & $\begin{array}{l}0.098^{* *} \\
(0.022)\end{array}$ & $\begin{array}{l}0.098 * * \\
(0.027)\end{array}$ & $\begin{array}{l}12.19^{* *} \\
(3.922)\end{array}$ & $\begin{array}{l}9.660^{* *} \\
(3.216)\end{array}$ \\
\hline PPPI & $\begin{array}{l}-0.066^{* *} \\
(0.016)\end{array}$ & $\begin{array}{l}-0.066^{* *} \\
(0.016)\end{array}$ & $\begin{array}{l}-0.043^{* *} \\
(0.015)\end{array}$ & $\begin{array}{c}-5.930^{*} \\
(2.787)\end{array}$ & $\begin{array}{l}-3.940 \\
(2.232)\end{array}$ \\
\hline GDP60 & & $\begin{array}{l}0.57 \mathrm{E}-3 \\
(0.44 \mathrm{E}-2)\end{array}$ & $\begin{array}{l}-0.011^{*} \\
(0.46 \mathrm{E}-2)\end{array}$ & $\begin{array}{l}3.765^{* *} \\
(0.735)\end{array}$ & $\begin{array}{l}2.918^{* *} \\
(0.634)\end{array}$ \\
\hline URBAN & & & & $\begin{array}{l}0.066 \\
(0.060)\end{array}$ & $\begin{array}{l}0.077 \\
(0.051)\end{array}$ \\
\hline PGOVCH1 & & & & $\begin{array}{c}-43.30^{*} \\
(18.84)\end{array}$ & \\
\hline PMAJCH1 & & & & & $\begin{array}{l}-179.2^{* *} \\
(28.30)\end{array}$ \\
\hline $\begin{array}{l}\text { no. obs. } \\
\text { adj. R2 }\end{array}$ & $\begin{array}{l}101 \\
0.54 \\
\end{array}$ & $\begin{array}{l}101 \\
0.53 \\
\end{array}$ & $\begin{array}{l}72 \\
0.58 \\
\end{array}$ & $\begin{array}{l}101 \\
0.56 \\
\end{array}$ & $\begin{array}{l}101 \\
0.67 \\
\end{array}$ \\
\hline
\end{tabular}

Note: OLS regressions, standard errors in parenthesis.

* $\left({ }^{* *}\right)$ denotes significance at the $5(1) \%$ level. 
Table 4

Cross-regressions on investment and institutional quality: Alternative $\lambda$-index

\begin{tabular}{llll}
\hline \hline Expl.var. & $\begin{array}{l}\text { INV } \\
(4 \mathrm{a})\end{array}$ & $\begin{array}{l}\text { BERIS } \\
(4 \mathrm{~b})\end{array}$ & $\begin{array}{l}\text { BERIS } \\
(4 \mathrm{c})\end{array}$ \\
\hline Constant & $0.090^{* *}$ & 4.253 & $10.12^{* *}$ \\
& $(0.025)$ & $(2.526)$ & $(1.237)$ \\
BERIS & $\begin{array}{l}0.71 \mathrm{E}-2^{* *} \\
(0.25 \mathrm{E}-2)\end{array}$ & & \\
& & & \\
PRIM & $0.109^{* *}$ & $3.451^{*}$ & $2.373^{*}$ \\
& $(0.027)$ & $(1.320)$ & $(0.915)$ \\
& & & \\
PPPI & $-0.059^{* *}$ & -0.020 & -0.490 \\
& $(0.015)$ & $(0.800)$ & $(0.521)$ \\
PGOVCH1 & & -0.877 & \\
& & $(7.458)$ & \\
PMAJCH1 & & & $-47.06^{* *}$ \\
& & & $(7.141)$ \\
GDP60 & & & \\
& & $(0.212)$ & $(0.148)$ \\
URBAN & & $0.73 \mathrm{E}-2$ & 0.025 \\
& & $(0.018)$ & $(0.013)$ \\
\hline no. obs. & 49 & 49 & 49 \\
adj.R2 & 0.65 & 0.60 & 0.80 \\
\hline \hline
\end{tabular}

Note: OLS regressions, standard errors in parenthesis.

* (**) denotes significance at the $5(1) \%$ level. 
Table 5

Cross-section regressions on institutional quality

\begin{tabular}{lllll}
\hline \hline & $\begin{array}{l}\text { ICRGS } \\
\text { Expl.var. }\end{array}$ & $\begin{array}{l}\text { ICRGS } \\
(5 \mathrm{a})\end{array}$ & $\begin{array}{l}\text { ICRGS } \\
(5 \mathrm{c})\end{array}$ & $\begin{array}{l}\text { ICRGS } \\
(5 \mathrm{~d})\end{array}$ \\
\hline Constant & $24.58^{* *}$ & $38.24^{* *}$ & $23.97^{* *}$ & $33.96^{* *}$ \\
& $(8.239)$ & $(7.458)$ & $(5.136)$ & $(3.893)$ \\
PRIM & 10.97 & 5.956 & 6.096 & 5.561 \\
& $(6.257)$ & $(4.915)$ & $(3.823)$ & $(3.232)$ \\
PPPI & $-9.673^{*}$ & $-9.917^{* *}$ & -3.552 & -2.729 \\
& $(4.501)$ & $(3.644)$ & $(2.572)$ & $(2.076)$ \\
& & & & \\
GDP60 & $3.675^{* *}$ & $2.759^{* *}$ & $3.308^{* *}$ & $2.644^{* *}$ \\
& $(1.054)$ & $(0.957)$ & $(0.703)$ & $(0.620)$ \\
& & & & \\
URBAN & 0.047 & 0.117 & 0.050 & 0.075 \\
& $(0.094)$ & $(0.084)$ & $(0.059)$ & $(0.051)$ \\
PGOVCH1 & -46.37 & & -23.24 & \\
& $(30.83)$ & & $(17.62)$ & \\
& & & & \\
PMAJCH1 & & $-161.4^{* *}$ & & $-144.0^{* *}$ \\
& & $(40.68)$ & & $(27.36)$ \\
INCOME & $23.73^{*}$ & 6.893 & & \\
& $(10.4)$ & $(8.615)$ & & \\
POLA. R2 & & & $-4.105^{* *}$ & $-3.476^{* *}$ \\
\hline \hline & & & $(0.936)$ & $(0.824)$ \\
\hline
\end{tabular}

Note: OLS regressions, standard errors in parenthesis.

* $\left({ }^{* *}\right)$ denotes significance at the $5(1) \%$ level. 
Table 6

Cross-section regressions on investment

\begin{tabular}{|c|c|c|c|c|}
\hline Expl.var. & $\begin{array}{l}\text { INV } \\
(6 \mathrm{a}) \\
\end{array}$ & $\begin{array}{l}\text { INV } \\
(6 \mathrm{~b})\end{array}$ & $\begin{array}{l}\text { INV } \\
(6 \mathrm{c}) \\
\end{array}$ & $\begin{array}{l}\text { INV } \\
(6 \mathrm{~d}) \\
\end{array}$ \\
\hline Constant & $\begin{array}{l}0.134^{* *} \\
(0.034)\end{array}$ & $\begin{array}{l}0.168^{* *} \\
(0.036)\end{array}$ & $\begin{array}{l}0.096^{* *} \\
(0.032)\end{array}$ & $\begin{array}{l}0.117^{* *} \\
(0.022)\end{array}$ \\
\hline ICRGS & $\begin{array}{l}0.18 \mathrm{E}-2^{* *} \\
(0.52 \mathrm{E}-3)\end{array}$ & $\begin{array}{l}0.12 \mathrm{E}-2^{*} \\
(0.60 \mathrm{E}-3)\end{array}$ & $\begin{array}{l}0.18 \mathrm{E}-2^{*} \\
(0.77 \mathrm{E}-3)\end{array}$ & $\begin{array}{l}0.17 \mathrm{E}-2^{* *} \\
(0.62 \mathrm{E}-3)\end{array}$ \\
\hline PRIM & $\begin{array}{l}0.109^{* *} \\
(0.024)\end{array}$ & $\begin{array}{l}0.112^{* *} \\
(0.021)\end{array}$ & $\begin{array}{l}0.106^{* *} \\
(0.029)\end{array}$ & $\begin{array}{l}0.098^{* *} \\
(0.021)\end{array}$ \\
\hline PPPI & $\begin{array}{l}-0.070^{* *} \\
(0.017)\end{array}$ & $\begin{array}{l}-0.068^{* *} \\
(0.016)\end{array}$ & $\begin{array}{l}-0.083^{* *} \\
(0.026)\end{array}$ & $\begin{array}{l}-0.065^{* *} \\
(0.016)\end{array}$ \\
\hline PGOVCH1 & $\begin{array}{l}-0.085 \\
(0.110)\end{array}$ & & & \\
\hline PMAJCH1 & & $\begin{array}{l}-0.417 \\
(0.230)\end{array}$ & & \\
\hline INCOME & & & $\begin{array}{l}0.089 \\
(0.061)\end{array}$ & \\
\hline POLAR & & & & $\begin{array}{l}-0.43 \mathrm{E}-2 \\
(0.71 \mathrm{E}-2) \\
\end{array}$ \\
\hline $\begin{array}{l}\text { no. obs. } \\
\text { adj. R2 }\end{array}$ & $\begin{array}{l}101 \\
0.54 \\
\end{array}$ & $\begin{array}{l}101 \\
0.55 \\
\end{array}$ & $\begin{array}{l}49 \\
0.59 \\
\end{array}$ & $\begin{array}{l}98 \\
0.54 \\
\end{array}$ \\
\hline
\end{tabular}

Note: OLS regressions, standard errors in parenthesis.

${ }^{*}\left({ }^{* *}\right)$ denotes significance at the $5(1) \%$ level. 
Table 7

Seemingly Unrelated Regression (SUR)

\begin{tabular}{|c|c|c|c|c|}
\hline Expl.var. & $\begin{array}{l}\text { INV } \\
(7 \mathrm{a}) \\
\end{array}$ & $\begin{array}{l}\text { ICRGS } \\
(7 \mathrm{~b})\end{array}$ & $\begin{array}{l}\text { INV } \\
(7 \mathrm{c}) \\
\end{array}$ & $\begin{array}{l}\text { ICRGS } \\
\text { (7d) }\end{array}$ \\
\hline Constant & $\begin{array}{l}0.111^{* *} \\
(0.020)\end{array}$ & $\begin{array}{l}26.00^{* *} \\
(5.432)\end{array}$ & $\begin{array}{l}0.107^{* *} \\
(0.020)\end{array}$ & $\begin{array}{l}35.92^{* *} \\
(4.035)\end{array}$ \\
\hline ICRGS & $\begin{array}{l}0.19 \mathrm{E}-2^{* *} \\
(0.51 \mathrm{E}-3)\end{array}$ & & $\begin{array}{l}0.22 \mathrm{E}-2^{* *} \\
(0.51 \mathrm{E}-3)\end{array}$ & \\
\hline PRIM & $\begin{array}{l}0.095^{* *} \\
(0.020)\end{array}$ & $\begin{array}{l}12.18^{* *} \\
(3.802)\end{array}$ & $\begin{array}{l}0.088^{* *} \\
(0.020)\end{array}$ & $\begin{array}{l}9.573^{* *} \\
(3.108)\end{array}$ \\
\hline PPPI & $\begin{array}{l}-0.065^{* *} \\
(0.016)\end{array}$ & $\begin{array}{l}-5.969^{*} \\
(2.702)\end{array}$ & $\begin{array}{l}-0.064^{* *} \\
(0.016)\end{array}$ & $\begin{array}{l}-3.948 \\
(2.165)\end{array}$ \\
\hline PGOVCH1 & & $\begin{array}{c}-43.91^{*} \\
(18.26)\end{array}$ & & \\
\hline PMAJCH1 & & & & $\begin{array}{l}-183.7^{* *} \\
(27.27)\end{array}$ \\
\hline GDP60 & & $\begin{array}{l}3.752^{* *} \\
(0.713)\end{array}$ & & $\begin{array}{l}2.840^{* *} \\
(0.611)\end{array}$ \\
\hline URBAN & & $\begin{array}{l}0.069 \\
(0.058) \\
\end{array}$ & & $\begin{array}{l}0.084 \\
(0.049) \\
\end{array}$ \\
\hline no. obs. & 101 & 101 & 101 & 101 \\
\hline
\end{tabular}

Note: SUR regressions, standard errors in parenthesis. Column (7a) \& (7b) and (7c) \& (7d) respectively are estimated jointly. * $\left(^{* *}\right)$ denotes significance at the 5 (1) \% level. 
Table 8

Simultaneous equation on investment and political instability

\begin{tabular}{|c|c|c|c|}
\hline Expl.var. & $\begin{array}{l}\text { INV } \\
(8 a) \\
\end{array}$ & $\begin{array}{l}\text { ICRGS } \\
(8 \mathrm{~b})\end{array}$ & $\begin{array}{l}\text { PMAJCH1 } \\
(8 \mathrm{c}) \\
\end{array}$ \\
\hline Constant & $\begin{array}{l}0.100^{* *} \\
(0.021)\end{array}$ & $\begin{array}{l}33.81^{* *} \\
(3.905)\end{array}$ & $\begin{array}{l}0.102^{* *} \\
(0.60 \mathrm{E}-2)\end{array}$ \\
\hline ICRGS & $\begin{array}{l}0.29 \mathrm{E}-2^{* *} \\
(0.70 \mathrm{E}-3)\end{array}$ & & \\
\hline PRIM & $\begin{array}{l}0.078 * * \\
(0.023)\end{array}$ & $\begin{array}{l}5.571 \\
(3.090)\end{array}$ & $\begin{array}{l}-0.30 \mathrm{E}-2 \\
(0.71 \mathrm{E}-2)\end{array}$ \\
\hline PPPI & $\begin{array}{l}-0.063^{* *} \\
(0.016)\end{array}$ & $\begin{array}{l}-2.715 \\
(2.002)\end{array}$ & \\
\hline PMAJCH1 & & $\begin{array}{l}-143.5^{* *} \\
(28.58)\end{array}$ & \\
\hline INV & & & $\begin{array}{l}-0.036 \\
(0.043)\end{array}$ \\
\hline POLAR & & $\begin{array}{l}-3.485^{* *} \\
(0.781)\end{array}$ & $\begin{array}{l}0.34 \mathrm{E}-2^{*} \\
(0.14 \mathrm{E}-2)\end{array}$ \\
\hline GDP60 & & $\begin{array}{l}2.445^{* *} \\
(0.586)\end{array}$ & $\begin{array}{l}0.17 \mathrm{E}-3 \\
(0.85 \mathrm{E}-3)\end{array}$ \\
\hline URBAN & & $\begin{array}{l}0.088 \\
(0.048)\end{array}$ & $\begin{array}{l}0.17 \mathrm{E}-3^{*} \\
(0.85 \mathrm{E}-4)\end{array}$ \\
\hline LATIN & & & $\begin{array}{l}0.058^{* *} \\
(0.32 \mathrm{E}-2)\end{array}$ \\
\hline AFRICA & & & $\begin{array}{l}0.71 \mathrm{E}-2^{*} \\
(0.33 \mathrm{E}-2)\end{array}$ \\
\hline no. obs. & 98 & 98 & 98 \\
\hline
\end{tabular}

Note: 3SLS regressions, standard errors in parenthesis.

$*\left({ }^{* *}\right)$ denotes significance at the $5(1) \%$ level. 
Table 9

Simultaneous equation on investment and political instability

\begin{tabular}{lccc}
\hline \hline Expl.var. & $\begin{array}{c}\text { INV } \\
(9 \mathrm{a})\end{array}$ & $\begin{array}{c}\text { ICRGS } \\
(9 \mathrm{~b})\end{array}$ & $\begin{array}{c}\text { FREQMCH } \\
(9 \mathrm{c})\end{array}$ \\
\hline Constant & $0.102^{* *}$ & $25.83^{* *}$ & $0.075^{*}$ \\
& $(0.021)$ & $(3.941)$ & $(0.60 \mathrm{E}-2)$ \\
ICRGS & $0.27 \mathrm{E}-2^{* *}$ & & \\
& $(0.71 \mathrm{E}-3)$ & & \\
PRIM & $0.077^{* *}$ & $10.67^{* *}$ & \\
& $(0.023)$ & $(3.771)$ & \\
PPPI & $-0.063^{* *}$ & -4.432 & \\
& $(0.016)$ & $(2.544)$ & \\
FREQMCH & & $-107.43^{* *}$ & \\
& & $(30.86)$ & \\
GDP60 & & $2.965^{* *}$ & \\
& & $(0.698)$ & \\
URBAN & & -0.100 & \\
& & $(0.059)$ & \\
INV & & & -0.057 \\
& & & $(0.150)$ \\
DATMAV & & & $0.133^{*}$ \\
& & & $(0.064)$ \\
REPRAV & & & $0.27 \mathrm{E}-3$ \\
& & & $(0.36 \mathrm{E}-3)$ \\
EXADJAV & & & 0.057 \\
& & & $(0.030)$ \\
GR5981 & & & -0.040 \\
LATIN & & & $(0.149)$ \\
AFRICA & & & $0.065^{* *}$ \\
& & & $(0.017)$ \\
no. obs. & 99 & & $0.016)$ \\
\hline \hline
\end{tabular}

Note: 3SLS regressions, standard errors in parenthesis. * $\left({ }^{* *}\right)$ denotes significance at the $5(1) \%$ level. 
Table 10

Cross-regressions on institutional quality: Sensitivity analysis

\begin{tabular}{lll}
\hline \hline Expl.var. & $\begin{array}{l}\text { ICRGS } \\
(10 \mathrm{a})\end{array}$ & $\begin{array}{l}\text { ICRGS } \\
(10 \mathrm{~b})\end{array}$ \\
\hline Constant & $\begin{array}{l}16.81^{* *} \\
(3.364)\end{array}$ & $\begin{array}{l}17.04^{* *} \\
(3.215)\end{array}$ \\
PRIM & $\begin{array}{l}10.59^{* *} \\
(3.878)\end{array}$ & $\begin{array}{l}10.10^{* *} \\
(3.745)\end{array}$ \\
& -3.793 & -3.529 \\
PPPI & $(2.637)$ & $(2.591)$ \\
& & \\
GDP60 & $3.581^{* *}$ & $3.338^{* *}$ \\
& $(0.741)$ & $(0.733)$ \\
& & \\
URBAN & 0.044 & 0.053 \\
& $(0.060)$ & $(0.059)$ \\
& & \\
FREQGCH & -9.096 & \\
& $(6.314)$ & \\
FREQMCH & & $-22.52^{*}$ \\
\hline no. obs. & 101 & $(9.831)$ \\
adj. R2 & 0.54 & 0.56 \\
\hline \hline
\end{tabular}

Note: OLS regressions, standard errors in parenthesis.

* $\left({ }^{* *}\right)$ denotes significance at the $5(1) \%$ level. 
Table 11

Cross-regressions on investment and institutional quality: Developing countries only

\begin{tabular}{|c|c|c|c|c|}
\hline Expl.var. & $\begin{array}{l}\text { INV } \\
(11 \mathrm{a})\end{array}$ & $\begin{array}{l}\text { INVP } \\
(11 b) \\
\end{array}$ & $\begin{array}{l}\text { ICRGS } \\
(11 \mathrm{c})\end{array}$ & $\begin{array}{l}\text { ICRGS } \\
\text { (11d) }\end{array}$ \\
\hline Constant & $\begin{array}{l}0.114^{* *} \\
(0.026)\end{array}$ & $\begin{array}{l}0.043 \\
(0.030)\end{array}$ & $\begin{array}{l}33.19^{* *} \\
(5.700)\end{array}$ & $\begin{array}{l}33.16^{* *} \\
(4.563)\end{array}$ \\
\hline ICRGS & $\begin{array}{l}0.15 \mathrm{E}-2^{*} \\
(0.74 \mathrm{E}-3)\end{array}$ & $\begin{array}{l}0.33 \mathrm{E}-2^{* *} \\
(0.83 \mathrm{E}-3)\end{array}$ & & \\
\hline PRIM & $\begin{array}{l}0.102^{* *} \\
(0.022)\end{array}$ & $\begin{array}{l}0.085^{* *} \\
(0.028)\end{array}$ & $\begin{array}{l}8.308 \\
(4.200)\end{array}$ & $\begin{array}{l}7.046 \\
(3.921)\end{array}$ \\
\hline PPPI & $\begin{array}{l}-0.064^{* *} \\
(0.017)\end{array}$ & $\begin{array}{l}-0.039^{*} \\
(0.016)\end{array}$ & $\begin{array}{l}-7.159^{*} \\
(2.722)\end{array}$ & $\begin{array}{l}-4.342 \\
(2.413)\end{array}$ \\
\hline PGOVCH1 & & & $\begin{array}{l}-54.99^{* *} \\
(19.21)\end{array}$ & \\
\hline PMAJCH1 & & & & $\begin{array}{l}-134.83^{* *} \\
(34.11)\end{array}$ \\
\hline GDP60 & & & $\begin{array}{l}0.397 \\
(1.218)\end{array}$ & $\begin{array}{l}1.047 \\
(1.186)\end{array}$ \\
\hline URBAN & & & $\begin{array}{l}0.122 \\
(0.068) \\
\end{array}$ & $\begin{array}{l}0.094 \\
(0.064) \\
\end{array}$ \\
\hline $\begin{array}{l}\text { no. obs. } \\
\text { adj.R2 }\end{array}$ & $\begin{array}{l}77 \\
0.42 \\
\end{array}$ & $\begin{array}{l}49 \\
0.54 \\
\end{array}$ & $\begin{array}{l}77 \\
0.20\end{array}$ & $\begin{array}{l}77 \\
0.26\end{array}$ \\
\hline
\end{tabular}

Note: OLS regressions, standard errors in parenthesis. * $\left({ }^{* *}\right)$ denotes significance at the $5(1) \%$ level. 